\title{
Long-Run Performance of an Industry after Broader Reforms including Privatization
}

\author{
Yaseen Ghulam ${ }^{\mathrm{a}, \mathrm{b}}$ \\ ${ }^{\text {a }}$ University of Portsmouth, Portsmouth Business School, \\ Economics and Finance Subject Group \\ Richmond Building, Portland Street, PO1 3DE, UK \\ Email: yaseen.ghulam@port.ac.uk \\ Phone: +442392844127

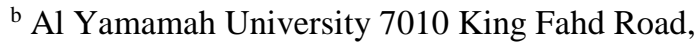 \\ Al Qirawan, Riyadh 13541, Saudi Arabia
}




\section{Long-Run Performance of an Industry after Broader Reforms including Privatization}

\section{Highlights}

- The empirical evidence on the long-run impact of reforms on industry is limited.

- We evaluate the long-run performance of the privatized firms and their competitors.

- $\quad$ Our sample cement industry is from an emerging market facing much turmoil.

- The long-term financial profitability/efficiency of privatized firms has declined.

- Technical progress, not efficiency, has brought long-run productivity growth. 


\title{
Long-Run Performance of an Industry after Broader Reforms including Privatization
}

\begin{abstract}
Research on the impacts of broader reforms, including privatization on firms' long-run financial and operational performance, is extremely important but only occasionally performed. This study evaluates the long-run financial performance, total factor productivity, efficiency and technology of Pakistani cement manufacturing firms. We conclude that privatized firms have in fact achieved significant productivity growth in the long run due to technological progress compared to no growth in the pre-reform period. Interestingly, however, better productive performance has not contributed to long-run profitability and income efficiency gains, thereby casting serious doubt on the long-run financial benefits of reforms, including privatization.
\end{abstract}

JEL classification: D24, D41, D42, L25, L33, L61

Keywords: privatization; reforms; productivity; technical change; financial performance; cement industry; Pakistan 


\section{Introduction}

Following the lead from the developed countries, a significant number of governments in developing countries have implemented privatization programmes since the early 1980 s to let the market economy function and to use the subsidies allocated to public enterprises for the social sector in general and poverty reduction in particular. Boubakri et al. (2008), in regard to the objectives of privatization, stated that the "primary aim is to reduce the role of the government as a dominant actor (stakeholder) in the economy and to favour the emergence of an active private sector". In terms of evaluation of the success of these policies, despite the significant efforts in comparing the performance of firms in pre- and post-privatization periods, conclusions drawn from these studies are still not clear. These mixed messages regarding the success/failure of the privatization programmes are adding fuel to uncertainty. One of the consequences of all this is that governments in some developing countries, despite their best efforts, have been unable to sell larger public sector corporations and utility companies.

There could be a number of reasons contributing to the contrasting conclusions drawn: first, some authors, such as Galal et al. (1994), argued that the success of the privatization policy varies by countries depending on the level of economic development. Surprisingly, despite the growing literature on the impact of privatization in developed countries, only a remarkably few studies, including Saygili and Taymaz (2001), Chirwa (2004), Bartel and Harrison (2005) and Okten and Arin (2006), have looked into the long-term ex post productive and financial performance of the privatized enterprises in developing countries. This was corroborated by Boubakri et al. (2008) who, when reviewing the performance of privatized firms in developing countries, stated that "in spite of the growing importance of the privatization phenomenon in developing countries, it is 
surprising that only a few studies have examined the impact of privatization on firm performance in these countries". Furthermore, some developing countries such as Pakistan have witnessed unparalleled political and religious turmoil since the launch of the privatization programme back in the early 1990s. Hence, conclusions drawn from empirical studies of developed countries in general, and Pakistan in particular, could be different and difficult to generalize for developed or other developing countries.

Second, most of the early influential studies on the impact of privatization and broader reforms, such as Megginson et al. (1994), Galal et al. (1994) and Barberis et al. (1996), used only a few years of post-privatization data to understand the immediate short-term impact of privatization. Barberis et al. (1996) in this regard clearly stated: "Nonetheless, our approach is useful if one wants to understand how particular privatization strategies can have immediate effects." The improved short run financial and operational performance of privatized firms could have been due to changes in industry and economic conditions alongside other exogenous factors rather than ownership change per se. Similarly, it has been argued that the short-term impact of privatization could be negligible in some industries if restructuring is not introduced at the time of privatization or the entry of new firms is not ensured immediately after privatization, particularly in an oligopolistic competition environment.

The third reason, and a very important one, is the nature of the industry being analysed. The privatization and deregulation policy aims to address the issues of market power and the promotion of higher competition resulting in better productive performance, but for some industries, broader reforms, including privatization, could lead to even lower competition levels due to illegal 
collusion practices resulting in no change in efficiency/productivity, or even worse a decrease. The interlinkage between competition and firm performance was reiterated by Asaftei et al. (2008) who concluded that fully private firms performed better than public sector firms when firms were operating in a competitive environment. Hence, privatization in conjunction with the creation of a competitive environment delivers the required results.

Specifically, in some industries, such as the cement industry, there is a greater potential for forming a cartel in the long run. This is due to the higher sunk cost of setting up a cement manufacturing plant, developing limestone and other raw material quarries to source inputs and the maintenance of raw material inventories etc. This discourages the entry of new firms as well as forcing existing smaller-sized firms, in particular, to exit and thus pave the way for explicit/tacit collusion. The collusion could be further helped by the post-privatization decrease in the number of producers due to the merger of smaller firms with larger ones in seeking to utilize scale economies. Not surprisingly, there has also been continued international interest in the assessment of competitive conditions in the cement industry right across the world for many years ${ }^{1}$. Not surprisingly, since the mass privatization of the cement industry in Pakistan in 1991/92 as well as post-reform mergers and acquisitions, there have also been serious allegations of collusion among Pakistani cement manufacturers.

\footnotetext{
${ }^{1}$ Some of these studies include Zeidan and Resende (2009) and Salvo (2010) for Brazil, Hüschelrath and Veith (2013) for Germany, Rosenbaum and Sukharomana (2001) for the USA, Çelen and Gunalp (2010) for Turkey, Bejger (2012) for India, Steen and Sørgard (1999) for Norway, and Bejger (2011) for Poland.
} 
One of the primary objectives of this study is to address the above-mentioned issues and establish whether or not the privatization and broader reforms have resulted in a better long run financial performance and more efficient production operation within the Pakistani cement industry. Except for Ghulam and Jaffry (2015), no comprehensive study of the productive performance has been carried out since the privatization of the cement industry in Pakistan. The few studies we have come across on post-privatization performance evaluation lacked rigour and mostly used financial ratios on a selected number of firms. This was probably due to a lack of research culture and data availability issues. We extend the Ghulam and Jaffry framework in estimating total factor productivity by further estimating the components of efficiency change (such as pure efficiency change and scale efficiency change) and technical change (i.e. pure technical change and change in the scale of technology) alongside an analysis of the financial performance of the industry by utilizing commonly used financial indicators.

Similarly to a significant number of studies that have utilized a single industry, we have a small number of observations to estimate cross-period distance functions to be used subsequently to calculate productivity growth and its components and hence could have less reliable productivity estimates using Data Envelopment Analysis (DEA) due to the well-known convergence issues. To overcome some of the inherent issues with the DEA estimator, we bootstrap the productivity and its sources and carry out statistical inferences as well as supplementing the analysis by looking at similar-type firms from five industries belonging to the Pakistani manufacturing industry who experienced broader reforms including privatization at the same time and ownership transfer method for both the long run financial and productive performance analysis. 
Our study utilizes data on almost all cement manufacturing firms in Pakistan over 26 years, covering the period of pre- (six years) and post- (20 years) privatization and broader reforms. The duration of our study covers four business cycles, six political governments and one military regime, each with its own strategy/policy, but with a common agenda: "let the private sector grow and function". Pakistan, being one of many developing countries with an underdeveloped economy, has an extremely low per capita income and the highly unstable political system alongside been badly affected by terrorism activities provides an interesting setting. The study aims to provide a valuable extension of the existing international literature on the long-term impact of privatization generally and on developing countries' manufacturing sector in particular. As far as we are aware, except for the studies of Chirwa (2004) and Ghulam and Jaffry (2015), our long sample period exceeds that of other studies of developing countries on this issue.

Our findings regarding pre- and post-reform cement manufacturer firms' financial performance can be summarized as follows. First, on average, except for privately owned firms, industry, as well as a group of privatized and public (state-owned) firms, experienced a long-run decline in profitability in the overall post-reform (1992 onward) period. Second, any improvement in labour use efficiency in the group of privatized firms in the initial years of the post-privatization period, perhaps due to rationalization of the workforce, was lost within a few years. Third, real median sales increased for the entire industry as well as for the group of private firms over a longer postreform period, and the increase was statistically significant too. However, this cannot be said of privatized firms. For the overall industry, and the group of private firms, most improvement came during the longer-term post-reform period (1999 to 2011). 
Fourth, for the overall post-reform period, as well as for the immediate first seven years, the group of private and privatized firms experienced an increase in capital spending but the improvement was statistically significant only for the privatized firms. Fifth, when cement industry performance is compared against other similar firms from the manufacturing industry that also experienced privatization almost at the same time, the estimates show that except for privatized firms in the automobile industry, firms belonging to all other comparable industries did not improve their profitability in the short or long run in the post-reform period. The automobile industry, however, enjoys a significant monopoly power. Sixth, in another sensitivity analysis exercise, we look at two other industries that did not experience privatization, and broadly speaking, our main conclusions are that despite some marginal improvements, at least for one industry, the post-reform long-run financial performance outcomes of these two industries are not any better than other industries irrespective of choice of indicator and post-reform time periods.

When cement industry productive performance during pre- and post-reform periods is evaluated, the conclusions can be summarized as follows. First, the industry witnessed a more than three per cent growth during the post-reform period, with technological progress being the sole contributor, compared to the negative growth before the reforms. In particular, during the longer-term postreform period (since 1999), industry has done exceptionally well. Second, privatized firms showed no productivity growth under public sector ownership (1987-1991), but more than 2 per cent p.a. after change of ownership. The growth in productivity was achieved due to the technological development despite a decline in efficiency. For the initial post-privatization period (1992-1999), similarly to the industry, the group of privatized firms did not show any improvement/decline in productivity. An improvement in the technological growth was offset by a decline in efficiency. 
Hence, improvement in productivity for privatized firms came in the longer-term postreform/privatization period. Interestingly, firms were able to move to best-practice frontier firms during the longer run post-reform period. The productivity growth would perhaps have been even higher if firms had been able to utilize their production capacity better and had achieved higher scale efficiency. They were unable to do this due to significant capacity additions resulting in excess capacity of the industry, particularly from 1999 onward.

Third, firms that remained under state ownership after the mass privatization in 1992 did not perform any better during the periods 1987-1991 and 1992-99. In particular, during 1992-99, an impressive technological progress of more than 5 per cent p.a. was swallowed up by a decline in efficiency due to operating at suboptimal level perhaps due to outdated technology and tough competition from private and privatized firms. For the private firms, similarly to their peer groups, no significant productivity growth was achieved during the pre-reform period, while in the postreform/privatization period, this group of firms recorded an impressive performance with more than 4 per cent growth p.a. with the contribution of technological progress (negligible efficiency increase). These estimates are more than 9 per cent growth p.a. during the period 1999 to 2011 with technological progress of more than 9 per cent p.a. (no contribution from efficiency improvement again).

Fourth, after carrying out the sensitivity analysis we could conclude that in contrast to the cement industry, except for smaller-size and less capital-intensive industries such as cooking oil, engineering, chemical and automobile either experienced no improvement in productivity or indeed a decline over five and ten years in the post-reform and privatization period. This decline 
in productivity is also confirmed after dividing the sample firms into different ownerships such as public, privatized and private. Interestingly, in the industries where there is evidence of significant productivity gains, in complete contrast to the cement industry, improvement in productivity has been as a result of the catching up of the efficiency frontier (efficiency improvement) rather than the shifting of the frontier (technological progress). Fifth, multivariate regression results confirm that rather than just change of ownership, other factors such as pressure and burden of financial expenses, demand conditions and population contributed positively to the productivity growth of the cement industry.

The structure of the rest of the paper is such that Section two provides justification of the study by highlighting that why is a longitudinal study of the long-run impact of privatization needed. Section three provides a summary of the empirical literature on the impact of reforms on firms' financial and productive performance. The next two sections present an overview of the Pakistani privatization programme and the development in the cement industry. Section six covers the conceptual framework and the techniques used for financial performance evaluation and productivity estimation. Data and financial performance analysis, alongside productivity and its more elaborate components (sources), are presented in Sections seven and eight. The last section (nine) is dedicated to a summary of the conclusions drawn.

\section{Why is a longitudinal study of the long-run impact of privatization needed generally and Pakistan in particularly?}

As discussed above and in the literature review later on, a significant number of existing empirical studies that have evaluated the impact of broader reforms, including privatization, have used a 
sample with a relatively shorter time span, covering at most five to seven years of the post-reform period. As discussed above, we believe that this could have contributed to misleading conclusions regarding the long-run dynamic impact of reforms on individual firms, the entire industry, consumers and the government. In the following, we briefly discuss why it is important to distinguish between the short- and long-run impact of reforms and the consequences of ignoring post-reform dynamic changes spreading over a longer time period (many years).

\section{Collusion after privatization}

The easing of new firms' entry and freedom in setting prices, subsequent to reforms, brings the potential of the formation of a cartel by these privatized firms themselves, or they could be part of industry-wide collusion. The formation of collusion could have serious implications for the longrun financial and productive performance of the privatized firms as well as for the entire industry. Politically, it would be damaging for the privatization policy itself as well as for consumer welfare. By observing firms over a longer period of time, we would be able to better understand the dynamic effects of privatization on competitive conditions in an industry where the presence of sunk cost makes it a perfect candidate for an overt or explicit collusion.

\section{Business cycles and distortions}

Broadly speaking, in evaluating the short- and medium-term impact of privatization, two sets of methodologies have been used: financial ratios and efficiency/productivity estimates. Financial ratios over three to five years pre and post privatization have been widely used in empirical literature. The second strand of literature in this regard used parametric or non-parametric techniques to measure efficiency (profit, cost, production). In general, the impact of privatization 
has been understood to appear instantly. That is, most of the expected effect on efficiency and productivity would have occurred in the early years after privatization (or even with the announcement of privatization or before), but due to the cyclical nature of some businesses, conclusions drawn from short-term impacts could be misleading. By evaluating privatized firms over a short time span, the potential of noise in the data and abnormal profitability or productivity estimates cannot be ruled out. Hence, profitability/efficiency/productivity estimates derived from a longer sample period are likely to be more robust to economic fluctuations as well as short-term distortions introduced by a particular government action.

\section{Dynamic impacts}

It takes a considerable time for firms to make adjustments to the input mix, in order to achieve the optimal scale of production and the expansion of production capacity to realize economies of scale. Years of under-investments under public ownership would also lead to the need for a significant long-term investment in technology upgrades after privatization of these firms. Analysis spread over the longer post-privatization period would indicate a more dynamic impact of reforms in terms of firms making adjustment in the use and combination of labour, capital, energy mix and raw material, in particular, to achieve the best combination alongside operating at optimal scale.

\section{'Wait and see' policy}

Adjusting to a changed operational, economic and competitive environment also takes time and firms may adopt a 'wait and see' policy to assess the new environment and then make use of newly acquired operational freedom in adjusting input/output levels. A changed competitive environment could also force firms to think beyond the domestic market and start exporting surplus production 
as a result of significant investment in capacity additions. The new management of privatized firms could wait a few years to learn about new market and competitor experience in exporting. Hence, the impact of learning by exporting could only be gauged by utilizing sample spreading over a longer time span. This 'wait and see' policy could also be the result of a contract signed with the government at the time of transfer of management with respect to labour retrenchment. Similarly to other countries, the new management of cement-producing privatized firms in Pakistan also signed a contract after compensation to the workers of state-owned firms through a 'golden handshake' (severance scheme). Hence, a longitudinal study, spread over a longer postprivatization period into the financial and operating performance of privatized firms is more appropriate and desirable to observe the full extent of labour adjustments made by the new management.

\section{Fiscal impact - compensation of lost revenues of SOEs by direct and indirect tax contributions}

One of the main stated aims of privatization of public sector firms has been to use privatization proceeds for the retirement of public debt as well as to reduce unaffordable subsidies. Another aim is that the national exchequer would be one of the main beneficiaries of the post-privatization improved performance of the privatized firms specifically and industry in general, by collecting more taxes due to higher sales and net earnings. This would compensate for the lost government revenues from the state-owned enterprises after transfer of ownership to the private sector. By focusing only on a few years of the post-privatization performance of privatized firms, we may not be able to capture the long-term tax contribution in the national kitty for the privatized firms in particular and industry in general. 


\section{Testing of economic theory in the presence of violations of assumptions}

There have been an ever increasing number of studies on the impact or effect of privatization since early 1980s. A simple search on Google scholar with the phrase "effect of privatization" with all these words present in the title produced 111 studies and changing the word 'effect' to 'impact' produced 408 studies. A sensible and interesting question in this regard is that why still there is a need to perform another study on the same topic. We believe that a Pakistani case study could contribute in the literature more due to a number of institutional, cultural and sociological factors. In modelling the consequences of change of ownership and other reforms, there are often underlying assumptions based on these factors which in some case are not valid in a particular case of a developing country such as Pakistan. In particularly, it is assumed that institutional framework is such that it promotes competition and price wars which results in competitive prices and fair play in terms of entry and exit. Strong but impartial institutions such as regulatory bodies, and legal system help control firms anticompetitive behaviour. The competition helps in achieving optimal production levels leading to an improvement in productive efficiencies. Similarly, cultural and sociological factors provide a setting which is conductive for fair play, and transparency as well free movement of labour and capital.

Parker and Kirkpatrick (2005) however, noted that these assumptions in relation to a developing country could not be true and identified six differences between developing and developed countries. These include competitive vs imperfect of product, labour, managerial labour and capital markets (competitive vs monopolized product market leading to distorted prices, hiring and firing of workers through competitive process vs appointments through connections, wellfunctioning and transparent capital market vs an under developed market and appointment of 
trained managers through competitive processes vs weak managers appointed through patronage), well understood and protected property rights vs unclear and inadequate protection of property rights alongside under developed business ethics and lastly high standard of honesty in government operations vs cronyism and corruption by democratic and non-democratic governments. Pakistan, being an underdeveloped country, suffered from all those weaknesses mentioned above but has made significant progress since 1999 onward in particular and 1991 in general. In the following, we briefly explain some of these developments in this regard.

Product, capital labour, and managerial markets: Immediately after the initiation of privatization policy, the government in the next fifteen years introduced a number of accompanying reforms including strengthening of regulatory bodies to control anticompetitive behaviour of privatized and non-privatized firms, reduction in labour union pressure and further privatization of state-owned firms and thus letting the private business to appoint an efficient labour and manager based on competitive wages and capital market regulation by removing restrictions on capital markets. This has led to an increase in the number of companies listed on country stock exchanges alongside market capitalization and liquidity. Despite all these developments, Pakistani press is full of news items on forming of cartels in cement, automobile, cooking oil, sugar and banking products. Capital market in general and stock markets in particular are often accused of insider trading and underhand deals. Transaction costs are still high compared to developed economies. The hiring and firing of workers and manager in government corporations is still based on political connections. Female labour force participation is low compared to western standards. Cultural and religious issues are dominants in discouraging female participation in the labour market. The presence of conglomerates and 
family run businesses in the private sector is hindering the competitive product, labour and managerial markets.

Private property rights, business conducts and ethics and transparency in government operations: Significant progress has been made in regard to private property rights in Pakistan. The courts and legal system has become more effective and efficient but still has a backlog of litigation cases related to ownership and other financial disputes. An improvement in the regulatory structure has helped to improve the standards of business conduct but cases of exploitation of labour and consumers are common. Transparency in government dealings varies depending upon which political party or dictatorship is in power. Pakistan is still counted among the most corrupt countries in the world which has resulted in the high cost of doing business. Religious terrorism and a precarious security situation have significantly hindered a government capacity to implement a strict code of business ethics for the last fifteen years in particular as well as discouraging foreign firm's entry.

In the presence of above mentioned issues alongside partial progress in Pakistani context, the study of a long term impact of privatization for a developing country such as Pakistan is an interesting read and a good addition in existing empirical literature.

\section{Evidence so far on the impact of broader reforms and privatization}

The literature on the question of ownership changes and their impact on performance has been updated regularly but is not conclusive. Some early studies in the 1980s and 1990s suggested that

performance under private ownership was superior and supported the positive impact of 
privatization. Among the widely cited studies supporting this conclusion are: Boardman and Vining (1989), Megginson et al. (1994), Galal et al. (1994), Barberis et al. (1996), Newbery and Pollitt (1997), Boubakri and Cosset (1998), Claessens and Djankov (1999) and D'Souza and Megginson (1999). Other authors such as Fare et al. (1985), Atkinson and Halvorsen (1986), Kay and Thompson (1986), Sappington and Stiglitz (1987), Wortzel and Wortzel (1989) and Laffont and Tirole (1991) do not consider public ownership an impediment to firms' efficient operation.

By using a relatively longer sample period, more effort has gone in to evaluating the financial and operational performance of firms in the pre- and post-privatization period since 2000 (see Table 1). This includes single as well as multi-country industry case studies. Similarly to earlier studies, the empirical literature does not seem to be conclusive. A significant number of authors such as Shirley and Walsh (2000), Megginson and Netter (2001), Dewenter and Malatesta (2001), D’Souza et al. (2002), Djankov and Murrell (2002), Wei and Varela (2003), Sun and Tong (2003), $\mathrm{Li}$ and $\mathrm{Xu}$ (2004) and Arocena and Oliveros (2012) concluded that firms under private ownership performed better. In contrast to this, some studies, such as those by Sall and Parker (2001), Saygili and Taymaz (2001) and Wang (2005), came to the opposite conclusion. Hence, it could be argued that although there is a vast international body of literature on the public-private efficiency comparison and the privatization effect itself, it lacks conclusiveness in terms of a long-lasting impact on firms' financial and operational performance.

In contrast to the ever-increasing worldwide literature, remarkably few studies have looked into the ex post performance of the privatized manufacturing firms in Pakistan. Notable among these are the studies by Aftab and Khan (1995), Naqvi and Kemal (1997) and more recently by Ghulam and Jaffry (2015). Aftab and Khan found that, contrary to the general perception, change of 
ownership resulted in less employment loss. Naqvi and Kemal, however, concluded that the effect of privatization on efficiency, output and price levels was uncertain. Ghulam and Jaffry (2015), using data on the Pakistani cement industry, concluded that the industry had experienced good long-run productivity growth due to technological progress. This study, however, ignored the financial aspect of the reforms and privatization. Further, sources of productivity growth were limited to efficiency and technical change. We extend the findings of the above-mentioned study significantly by estimating more sources of productivity growth alongside bootstrapping as well as financial performance evaluation and comparing these findings with a sample of firms from five Pakistani industries operating under a similar economic and regulatory framework. 


\section{Table 1: Some widely cited studies on post-reform/privatization performance evaluation}

\section{Authors $\quad$ Sample industry/firms $\quad$ Main results}

Financial performance evaluation studies

Bishop \& Kay (1989)

Adam \& Mistry (1992)

Megginson et al. (1994)

Galal et al. (1994)

Villalonga (2000)

Harper (2001)

Boubakri \& Cosset (2002)

Wei et al. (2002)

Boubakri et al. (2004)

D'Souza et al. (2005)

Boubakri et al. (2005)

Chen et al. (2006)

Mathur \& Banchuenvijit (2007)

Farinós et al. (2007)

Naceur et al. (2007)

Li et al. (2007)

Cook \& Uchida (2008)

Ghosh (2008)

Huang \& Wang (2011)

Zhang et al. (2012)

Productivity/efficiency evaluation 364 Chinese firms

Saal \& Parker (2000)

Rossi (2001)

Sall \& Parker (2001)

Chirwa (2001)

Saygili \& Taymaz (2001)

Estache et al. (2002)

Jones \& Mygind (2002)

Resende \& Faceanha (2002)

Cullinane \& Song (2003)

Chirwa (2004)

Brown et al. (2006)

Okten \& Arin (2006)

Amess \& Roberts (2007)

Sall et al. (2007)

Asaftei et al. (2008)

Saal \& Parker (2000)

Chirwa (2001)

Argentinian gas distribution companies 1993-97/8

UK water and sewerage firms 1985-99/10

Malawian manufacturing firms (private and privatized) 1970-97/6

Turkish cement firms (public, private, privatized and mixed) 1980-95/38

Argentinian and Brazilian railways companies 1994-99/16

Estonian manufacturing firms 1993-97/666

Brazilian telecommunication companies Jul. 98 and Dec. 99

Korean container terminal 1978-96/5

Malawian public, private and privatized firms 1970-97/15

Romanian, Hungarian, Ukrainian and Russian manufacturing firms 1986-92/30647

Turkish privatized cement companies 1983-99/22

Polish manufacturing cooperatives 1988-93/4525

English and Welsh water and sewerage firms 1985-2000/10

Romanian manufacturing firms 1995-2003/avg. 1106

UK water and sewerage firms 1985-99/10

Malawian manufacturing firms (private and privatized) 1970-97/6
Privatized firms grew faster than public sector firm

Privatization improved profitability and efficiency

Strong performance after privatization

Welfare gains in 11 out of 12 privatized companies analysed

Performance improved after privatization. Decline is transitional

Profitability and efficiency decreased

Performance did not improve

Performance improved

Performance improved

Performance improved

Performance improved

Decline in profitability and asset utilization

Performance improved

Performance improved

Performance improved

Profitability declined

Deterioration in performance among privatized utilities

Performance improved

Performance improved

Profitability decreased. Output and operating efficiency increased

Post-privatization efficiency improved due to better regulations rather than privatization per se Post-privatization efficiency improved due to technological progress and increase in efficiency Post-privatization no productivity improvement despite significant reductions in workforce Improved technical efficiency for all ownership firms after privatization

Change of ownership had no effect on technical efficiency

Productivity improved after privatization

Positive impact of privatization. Private firms more productive than state-owned firms Study documented no improvement in efficiency in post-privatization period

Privatization improved container productive efficiency

Technical efficiency improved after privatization. Competition and structural adjustment importan Positive impact of privatization on productivity (Romania, Hungary and Ukraine), negative for Russia Improved labour productivity after privatization

Firms improved productivity. Competition important

Did not show any improvement in productivity due to efficiency decline. Find technical progress

Privatized firms did not produce any better than public enterprises

Post-privatization efficiency improved due to better regulations rather than privatization per se Improved technical efficiency for all ownership firms after privatization 


\section{A brief history of the Pakistani privatization programme}

In contrast to the Western world, the rationale for privatization in Pakistan was not based on ideology, but rather on the necessity of the circumstances. By the end of the 1980s, a significant number of state-owned firms were making losses, leading to a significant increase in subsidies and budget deficit. Government fiscal space was gradually becoming limited due to a rising demand for public investment in crumbling infrastructure, debt servicing and defence outlays. This can be judged by the fact that by the end of $1987-88$, the fiscal deficit reached 8.5 per cent of GDP. By selling state-owned enterprises, it was expected that the government would be able to use subsidies allocated previously to these enterprises for building physical and social infrastructure. As a result of selling loss-making public enterprises, it was believed that private owners of these firms would address the inefficiencies in the production and distribution process and improve financial performance.

The first serious attempt to privatize state-owned enterprises was made in the early 1990s when the government introduced a mass privatization programme in 1991/92, which led to the selling of 66 manufacturing firms and two commercial banks to the private sector (see Table 2). A second phase of privatization was completed during 1993-96, when privatization of 20 manufacturing firms, one bank and one power generation plant and the selling of 12 per cent of shares in Pakistan Telecommunications Ltd. were completed. In the third phase, the efforts to privatize the remaining SOEs and financial institutions were intensified during 1999-2007. This time, however, the privatization programme was one of many initiatives to revive the economy. One of those initiatives included abolishing the 
culture of industrial patronage to promote competition and productivity. The privatization progress under this round included an 80 per cent sale of a national commercial bank. By the end of 2006, roughly 85 to 90 per cent of firms earmarked for the sale had already been sold to the private sector.

\section{Table 2: Details of privatized manufacturing firms}

\begin{tabular}{|c|c|c|c|c|c|c|c|}
\hline $\begin{array}{l}\text { Sector/ } \\
\text { Firm }\end{array}$ & Year & $\begin{array}{l}\text { Sector/ } \\
\text { Firm }\end{array}$ & Year & $\begin{array}{l}\text { Sector/ } \\
\text { Firm }\end{array}$ & Year & $\begin{array}{l}\text { Sector/ } \\
\text { Firm }\end{array}$ & Year \\
\hline Automobile & & Cement & & Chemical & & Cooking Oil & \\
\hline Al-Ghazi Tractors & 1991 & Maple Leaf Cement & 1992 & National Fibres & 1992 & Fazal Vegetable Ghee & 1991 \\
\hline National Motors & 1992 & Pak Cement & 1992 & Kurram Chemicals & 1992 & Associated & 1992 \\
\hline Millat Tractors & 1992 & White Cement & 1992 & Pak PVC & 1992 & Sh Fazal Rehman & 1992 \\
\hline Baluchistan Wheels & 1992 & D.G. Khan Cement & 1992 & Sind Alkalis & 1992 & Kakakhel & 1992 \\
\hline Pak Suzuki & 1992 & Dandot Cement & 1992 & Antibiotics & 1992 & United & 1992 \\
\hline Naya Daur Motors & 1993 & Garibwal Cement & 1992 & Swat Elutriation & 1994 & Haripur Vegetable Oil & 1992 \\
\hline Bolan Castings & 1993 & Zeal Pak Cement & 1992 & Nowshera PVC & 1995 & Bara Ghee Mills & 1992 \\
\hline Engineering & & Kohat Cement & 1992 & Swat Ceramics & 1995 & Hydari & 1992 \\
\hline Karachi Pipe Mills & 1992 & National Cement & 1995 & Ittehad Chemicals & 1995 & Chiltan Ghee Mills & 1992 \\
\hline Pioneer Steel & 1992 & General Ref. & 1996 & Pak Hye Oils & 1995 & Wazir Ali & 1992 \\
\hline Metropolitan Steel & 1992 & Wah Cement & 1996 & Ravi Engineering & 1996 & Asaf & 1993 \\
\hline Pakistan Switchgear & 1992 & Associated Rohri & 2003 & Nowshera Chemicals & 1996 & Khyber Vegetable & 1993 \\
\hline Quality Steel & 1993 & Thatta Cement & 2004 & National Petrocarbon & 1996 & Suraj Vegetable Ghee & 1993 \\
\hline Textile Machinery & 1995 & Mustehkam Cement & 2005 & & & Crescent Factories & 1993 \\
\hline \multirow[t]{9}{*}{ Indus Steel Pipe } & 1997 & Javedan Cement & 2006 & & & Bengal Vegetable & 1993 \\
\hline & & & & & & A \& B Oil & 1993 \\
\hline & & & & & & Dargai Vegetable & 1997 \\
\hline & & & & & & Punjab Veg. Ghee & 1999 \\
\hline & & & & & & Burma Oil & 2000 \\
\hline & & & & & & E\&M Oil Mills & 2002 \\
\hline & & & & & & Maqbool Oil & 2002 \\
\hline & & & & & & Kohinoor Oil Mills & 2004 \\
\hline & & & & & & United & 2005 \\
\hline
\end{tabular}

Source: Privatization Commission (PC), Government of Pakistan

Starting from 1996, the government also started focusing on financial reforms and the establishment of a regulatory framework. Accounting standards were refined to make them in line with international standards. The state central bank role, in regulating the banking industry, was 
strengthened. Other important reforms included stock exchange reforms, setting up and strengthening competition authorities, and strengthening the role of security and exchange commission etc. As a result of these far-reaching broader reforms, including privatization, the economy witnessed an impressive turnaround for at least a few years and the GDP growth peaked at 8 per cent in 2004 from the mere 3 to 4 per cent recorded in the previous ten years or more. Since then, however, a change of government focus and unsatisfactory progress in addressing the structural issues of the economy have stalled the economic growth trajectory. This has indeed led to an increase in unemployment levels and political unrest in the country.

The privatization of public utilities, banks and the airline has been 'work in progress' for a very long time now due to the less than satisfactory progress of the already privatized SOEs and a strong resistance from labour lobbies and the civil society. There had been little progress in this regard after almost completing three years of the current government who have put the speedy privatization of the remaining SOEs in their election manifesto as well as focusing on the development of the private sector. The lack of published empirical evidence on the subsequent performance of state owned firms compared to competitor private sector firms has also contributed to the confusion over the actual benefits of the Pakistani privatization programme. This study would, hopefully, contribute significantly to the ongoing debate on the effectiveness of reforms introduced a long time ago.

\section{Development of the Pakistani cement industry}

Cement manufacturing is a well-established industry in Pakistan, accounting for about 5.5 per cent of the total industrial production and representing 1.4 per cent of GDP. In 1972, after 
nationalization of the industry by the pro-socialist government, all the cement manufacturing plants were placed under the Board of Industrial Management. In response to the continuing shortages, the government lifted the ban on private investment in 1978 and announced an incentive package for private sector participation. A further deregulation in the cement industry started in 1984, when the first attempt was made by the state-run holding company State Cement Corporation of Pakistan (SCCP) to sell a percentage of the SCCP shares in two state-owned cement manufacturing firms. This was supplemented by allowing the managers of the state-owned firms to set output prices and source inputs without significant interference by the government. In 1991/92, under a 'mass privatization' programme, the government sold six cement manufacturing firms through a sealed bidding process. The privatization of four more firms was delayed but completed later on in 1996, 1999 and 2003 due to the non-payment of bidding money.

In a new and evolved institutional set-up after privatization and broader reforms, the government has no control on the production and selling of cement as against eighty five per cent market share before. A significant number of new privately owned firms had entered the market immediately after the start of the privatization policy, and some older firms had been acquired by competitor firms leading to consolidation of the industry. The existing firms had also undertaken a significant capital investment to expand their production capacities and replace old wet process production technology.

The cement manufacturing and distribution is being administered and monitored by a trade association, the All Pakistan Cement Manufacturers Association (APCMA). The industry has become the fifth largest exporter of cement in the world and has been exporting a significant 
quantity of cement to Afghanistan, Iraq, India, Djibouti, Tanzania, Sri Lanka and South Africa. The industry is providing employment for 250,000 workers directly and indirectly. The APCMA estimates the tax contributions towards the national kitty to be in the region of 30 billion Pakistani rupees. These are significant contributions against the backdrop of a struggling economy due to political turmoil, corruption, mismanagement, misplaced government priorities and regional terrorism.

Despite these developments, there are some serious allegations regarding the APCMA forming an tacit collusion and, in effect, replacing the state monopoly before the initiation of the privatization policy. The charge sheet included unreasonable price hikes maintained subsequently by a reduction in quantity supply that resulted in underutilization of the existing production capacity. There had been investigations by the competition authorities and as a result of these investigations, fines and warnings were issued to cement manufacturing firms. The APCMA, however, maintains that the members' cooperation is aimed at an adequate and fair supply across the country. Interestingly, despite a series of allegations and counter allegations, an internal study, carried out by the Competition Commission of Pakistan (CCP), was unable to find any clear collusion practice.

\section{Measurement of the impact of reforms on firms' performance}

A comprehensive evaluation of the impact of reforms on the industry would require a detailed assessment of firms' post-privatization pricing strategies, building of counterfactual scenarios, financial performance analysis, social cost benefit analysis and firms' response to the shift in technology frontiers and the catching up of best-practice firms. We carried out all these assessments, but due to the scope of this study, we focus only on the pre- and post-reform financial 
performance evaluation and firms' response to catching up with the industry benchmark as well as a shift in the frontier technology. The question of counterfactual scenarios is addressed by comparing privatized firms with those firms that were not privatized as well as those that were set up in the private sector and remained so throughout our sample period. We also compared the performance of the cement industry with other similar manufacturing industries to support our industry-specific explanation of the financial and productivity outcomes. In the following, we discuss the basic framework of our preferred methodologies in greater detail.

\subsection{Financial performance evaluation}

Similarly to the significant and ever-rising number of studies that have generally appeared in finance journals, we focus on five dimensions of financial performance: firms' profitability, net income efficiency (labour use efficiency in generating a surplus (profit)), output (inflation-adjusted sales/revenues), capital investment and the debt/leverage position. In the following, we briefly discuss these dimensions and explain the proxies that are used to evaluate the impact of reforms including privatization.

Profitability: One of the main objectives of privatization has been to make firms profitable to: 1) cover their operating expenses, 2) be able to make new investments, and 3) provide a reasonable return on shareholders' equity. Hence, we would like to find out whether this goal has been achieved for the group of privatized firms over shorter, medium and longer time periods. There are a number of proxy ratios that could serve as a profitability measure. However, following the wider practice in the empirical literature on this issue, we use the return on assets, which measures a firm's ability to manage its assets profitably. 
Efficiency: It is commonly argued that public enterprises suffer from innate inefficiency because they fail to utilize the available human resources efficiently. A sense of job security under public sector ownership alongside non-competitive in-cash wages and payments is perhaps considered the leading cause of poor labour use by managers and bureaucrats. After privatization, it is commonly argued that new private management would utilize labour resources more efficiently. Further, due to job insecurity and efficiency wages, workers would pay more attention to the production activities, which would result in improving labour productivity. We test this prediction by measuring net income efficiency, defined as net income, divided by the number of employees. This expresses the net surplus generated per employee during the year.

Output: It is expected that through improved incentives, more flexible financing opportunities, increased competition and a greater opportunity for entrepreneurial skills, real sales will increase after privatization (Megginson et al., 1994). However, after an extensive study of the performance of the Egyptian state-owned enterprises, Boycko et al. (1993) argued that effective privatization will lead to a reduction in output since the government will no longer be able to force and bribe managers to maintain a high level of output. We examine these competing predictions by using inflation-adjusted sales volume for post- and pre-privatization periods.

Investment: It is expected that a privatized firm will increase investment spending, for a variety of reasons, immediately after transfer of ownership. Firstly, privatized firms now have more options to source funds, including the equity market as well as from private finances. Secondly, immediately after privatization, these firms are expected to perform well in terms of earning power, which would provide them with an opportunity to utilize internal cash as well as capital market 
finances by floating new shares. Thirdly, these firms are usually sold primarily to established businesses in different industrial sectors with the ability to exploit the rising product demand by borrowing relatively easily in financial markets. Fourthly, investment in the upgrading of plants could be unavoidable due to years of financial stress during the state ownership period, which often led firms to defer even the most routine maintenance tasks, while not replacing the least efficient production technology or adding new capacities. A proxy ratio capital investment divided by net sales is computed and used to test the patterns in investment spending.

\subsection{Measure of productivity growth}

We closely follow the presentation of Wheelock and Wilson (1999) and Rezitis et al. (2009) in explaining our methodology. We assume that firms are operating in a competitive environment and want to maximize output subject to given inputs. Let's consider the number of $N$ firms using $p$ inputs in producing $q$ output over $T$ time period. Let's treat $\mathrm{x} \in \mathbb{R}_{+}^{\boldsymbol{p}}$ as an input vector and y $\in$ $\mathbb{R}_{+}^{\boldsymbol{q}}$ as an output vector of the sample firms. Further, let's say $\left(\mathrm{x}_{\boldsymbol{i}}^{\boldsymbol{t}}, \mathrm{y}_{\boldsymbol{i}}^{\boldsymbol{t}}\right)$ represents the input and output vector of the sample firm $i$ at time $t$. We can use the Shephard (1970) output distance function for firm $i$ at time $t+1$, relative to the technology at time $t$ as:

$$
D^{t+1}\left(\mathrm{x}_{i}^{t}, \mathrm{y}_{i}^{t}\right) \equiv \inf \left\{\theta>0 \mid \mathrm{y}_{i}^{t} / \theta \in Y^{t+1}\left(\mathrm{x}_{i}^{t}\right)\right\}
$$

We can derive three distance functions from the above equation (1): (i) $D^{t}\left(\mathrm{x}_{i}^{t}, \mathrm{y}_{i}^{t}\right)$ a measure of efficiency relative to contemporaneous technology; (ii) $D^{t}\left(\mathrm{x}_{i}^{t+1}, \mathrm{y}_{i}^{t+1}\right)$ a measure of the firm's position at time $t+1$ to the boundary of the production set at time $t$; and (iii) $D^{t+1}\left(\mathrm{x}_{i}^{t}, \mathrm{y}_{i}^{t}\right)$ a 
normalized measure of distance from the $i^{\text {th }}$ firm's position in the input/output space at time $t$ to the boundary of the production set at time $t+1$ in the hyperplane where inputs are constant. Empirically, $D^{t+1}\left(\mathrm{x}_{i}^{t}, \mathrm{y}_{i}^{t}\right)$ and $D^{t}\left(\mathrm{x}_{i}^{t+1}, \mathrm{y}_{i}^{t+1}\right)$ can be less than, equal to or greater than one, while $D^{t}\left(\mathrm{x}_{i}^{t}, \mathrm{y}_{i}^{t}\right)$ is likely to be less than or equal to one. The estimates of the above distance function (1) are generally obtained through linear programming by assuming the scale of the technology (constant/variable).

The three distance functions discussed above were used by Simar and Wilson (1998b) and Zofio and Lovell (1997) to decompose the Fare et al. (1989, 1992 and 1994) Malmquist index to estimate the change in the total factor productivity (TFP) of firms over time. Changes in the values of the index are captured by two sources: the shift in the firm's position relative to the production frontier over time (either through efficiency change or catch-up), and the shift in the production frontier over time (technical change or technological advancements). This index could be represented by the following:

$$
\begin{aligned}
\widehat{M}\left(t_{1}, t_{2}\right)= & {\left[\frac{\widehat{D}_{v}^{t_{2}}\left(\mathrm{x}_{i}^{t_{2}}, \mathrm{y}_{i}^{t_{2}}\right)}{\widehat{D}_{v}^{t_{1}}\left(\mathrm{x}_{i}^{t_{1}}, \mathrm{y}_{i}^{t_{1}}\right)}\right] \times\left[\frac{\widehat{D}_{c}^{t_{2}}\left(\mathrm{x}_{i}^{t_{2}}, \mathrm{y}_{i}^{t_{2}}\right) / \widehat{D}_{v}^{t_{2}}\left(\mathrm{x}_{i}^{t_{2}}, \mathrm{y}_{i}^{t_{2}}\right)}{\widehat{D}_{c}^{t_{1}}\left(\mathrm{x}_{i}^{t_{1}}, \mathrm{y}_{i}^{t_{1}}\right) / \widehat{D}_{v}^{t_{1}}\left(\mathrm{x}_{i}^{t_{1}}, \mathrm{y}_{i}^{t_{1}}\right)}\right] \times\left[\frac{\widehat{D}_{v}^{t_{1}}\left(\mathrm{x}_{i}^{t_{2}}, \mathrm{y}_{i}^{t_{2}}\right)}{\widehat{D}_{v}^{t_{2}}\left(\mathrm{x}_{i}^{t_{2}}, \mathrm{y}_{i}^{t_{2}}\right)} \times \frac{\widehat{D}_{v}^{t_{1}}\left(\mathrm{x}_{i}^{t_{1}}, \mathrm{y}_{i}^{t_{1}}\right)}{\widehat{D}_{v}^{t_{2}}\left(\mathrm{x}_{i}^{t_{1}}, \mathrm{y}_{i}^{t_{1}}\right)}\right]^{1 / 2} } \\
& \times\left[\frac{\widehat{D}_{c}^{t_{1}}\left(\mathrm{x}_{i}^{t_{2}}, \mathrm{y}_{i}^{t_{2}}\right) / \widehat{D}_{v}^{t_{1}}\left(\mathrm{x}_{i}^{t_{2}}, \mathrm{y}_{i}^{t_{2}}\right)}{\widehat{D}_{c}^{t_{2}}\left(\mathrm{x}_{i}^{t_{2}}, \mathrm{y}_{i}^{t_{2}}\right) / \widehat{D}_{v}^{t_{2}}\left(\mathrm{x}_{i}^{t_{2}}, \mathrm{y}_{i}^{t_{2}}\right)} \times \frac{\widehat{D}_{c}^{t_{1}}\left(\mathrm{x}_{i}^{t_{1}}, \mathrm{y}_{i}^{t_{1}}\right) / \widehat{D}_{v}^{t_{1}}\left(\mathrm{x}_{i}^{t_{1}}, \mathrm{y}_{i}^{t_{1}}\right)}{\widehat{D}_{c}^{t_{2}}\left(\mathrm{x}_{i}^{t_{1}}, \mathrm{y}_{i}^{t_{1}}\right) / \widehat{D}_{v}^{t_{2}}\left(\mathrm{x}_{i}^{t_{1}}, \mathrm{y}_{i}^{t_{1}}\right)}\right]^{1 / 2}
\end{aligned}
$$

where $x_{i}$ is the vector of inputs, $y_{i}$ is the vector of output and subscripts $c$ and $v$ are constant and variable returns to scale production technologies. Distance functions are estimated for two adjacent years $\left(t_{1}\right.$ and $\left.t_{2}\right)$. According to equation (2), Malmquist productivity index $\widehat{M}\left(t_{1}, t_{2}\right)$ is the combination of four components, namely pure efficiency change ( $\triangle \mathrm{PureEff})$, scale efficiency 
change $(\Delta \mathrm{Scale})$, pure change in technology $(\Delta \mathrm{PureTech})$ and the change in the scale of the technology ( $\Delta$ ScaleTech). Hence, productivity can improve due to better use of resources ( $\triangle$ PureEff $)$, operating at optimal scale $(\Delta$ Scale) or improvement in the use of technology ( $\Delta$ PureTech or $\Delta$ ScaleTech). Malmquist productivity index values greater than one would indicate an improvement (growth) and less than one a decline. The same applies to four components of productivity as well.

\section{Bootstrapping of productivity indices}

The idea of bootstrapping is to address the issue of the sensitivity of sample composition in relation to the efficiency scores. These resampled data, drawn from the observed data, are subsequently used to get repeated estimates of productivity. In this way, the approximation of the sampling distribution of the estimators is achieved through the empirical distribution of the simulated estimates. We follow Simar and Wilson's (1998a) bootstrapping method of the Malmquist productivity index. Bootstrapping allows us to assess the 'null hypothesis' of no change in productivity. We use 2000 draws for the resampling. If the 95 per cent upper and lower confidence interval contains unity, then we will be unable to reject the null hypothesis and the estimate is considered as not significantly different from one at the 5 per cent significance level (improvement/decline is statistically insignificant). When the confidence interval does not include unity, we conclude that the estimate is significantly different from unity (improvement/decline is statistically significant). An analogous procedure is used for the 90 per cent confidence interval, and the inferences are drawn at the 10 per cent significance level. Further, the significance of each component of productivity estimates is determined in a similar way. 


\section{Data and sources}

We employ a panel data set of the Pakistani cement manufacturing firms during the period 1986 to 2011. Our sample firms represent more than $95 \%$ of the industry. Our sample firms also represent three distinct ownerships type: state-owned, privately owned and privatized (formerly state-owned). We use firms' annual reports and data provided by the Pakistani Ministries for income and expenditure details as well as balance sheet items. This firm-specific information is used in the computing of financial ratios for financial performance evaluation. For firms' productive performance, we use data on firms' input use and output again extracted from firms' annual reports and other sources. We closely follow Ghulam and Jaffry (2015) in this regard in choosing of inputs and output for the cement manufacturer firms.

By using the relevant indices, output and input, variables in current prices are converted to constant prices of output and inputs. The firm's output is approximated by total gross sales and the real output/sale is worked out by deflating the nominal sales by the cement price index. Our output variable in values rather than quantity is similar to Bandyopadhyay (2011) and Tsckouras and Skuras (2005). The four inputs used in our study are the number of workers, fixed assets, expenditures on energy and fuel, and a residual category of expenditures on raw and packing material. Some authors used total man days instead of the number of workers. We do not have access to this data. Furthermore, the total man days proxy would be misleading in our case due to the poor law and order situation and strikes. Nonetheless, our measure is similar to Riccordi et al. (2012) and Ghulam and Jaffry (2015). 
The accounting measure of net fixed assets, which comprises the book value of property, plant and equipment, is used to capture the heterogeneity in production technology. We expect a higher value of these fixed assets for those firms that are using new advanced technology compared to the historical lower book value of old technology acquired a long time ago. Our measure is similar to Bandyopadhyay (2011). Fuel and energy account for more than 50 per cent of the production costs in the manufacturing of cement. We follow Saygili and Taymaz (2001) in using expenditures on fuel and energy and include this in our inputs combination. Similarly, expenditures on raw material are similar to Saygili and Taymaz (2001) and account for more than 18 per cent of the production cost. Real values of fixed capital, fuel expenses and raw material are calculated by deflating these accounts by the GDP deflator, fuel price index and raw material price index.

\section{Table 3: Summary statistics of the variables used in firms' productivity estimation}

\begin{tabular}{|c|c|c|c|c|c|c|}
\hline Variable & Scale & $\mathrm{N}$ & Mean & Std. Dev. & Minimum & Maximum \\
\hline Output value & Millions Rs. & 407 & 2859.45 & 3209.53 & 16.59 & 24038.63 \\
\hline Capital & Millions Rs. & 407 & 2535.85 & 2904.94 & 14.38 & 15140.4 \\
\hline Labour & Numbers & 407 & 716.51 & 412.05 & 110 & 2550 \\
\hline Material & Millions Rs. & 407 & 231.24 & 167.56 & 2.49 & 1142.25 \\
\hline Fuel & Millions Rs. & 407 & 735 & 582.82 & 8.46 & 4669.1 \\
\hline
\end{tabular}

Notes: $\mathrm{N}$ stands for number of observations calculated as firms*years.

Table 3 in particular shows descriptive statistics of inputs and output used in our study to derive productivity estimates and their sources. By looking at the table, it is clear that we have a significant heterogeneity in our sample of firms. The total number of observations for the whole sample period, after excluding a few outliers, is 407 with an average number of roughly 15 to 16 firms per year. The estimation of Malmquist productivity estimates and its components using 
equation (2) requires, first, calculation of the DEA-based cross-period eight distance functions by using data on inputs and output from two adjacent years. The fact that we are interested in yearly estimates means we could end up using too few observations.

A DEA estimator is known to be statistically less reliable when encountered with a smaller number of decision-making units (DMUs) or firms due to low convergence rates. Boussofiane et al. (1997) and Dyson et al. (2001) argued that to get meaningful estimates, the sample should at least fulfil the specific criteria and that the number of firms should be at least $2 *^{*} *_{0}$, where $i^{*} \mathrm{o}$ is the product of the number of inputs and outputs. In our case, the use of a DEA estimator with four inputs and single outputs would require a set of at least eight firms for each sample year. Our case study of firms fulfils this criterion reasonably well as our sample has more than 12 firms for all pre- and post-reform cross periods.

\section{Empirical findings}

\subsection{Pre and post reforms and privatization financial performance evaluation}

Table 4 shows the Wilcoxon test results of the firms' profitability, efficiency, output approximated by real sales and capital expenditure. Starting with profitability, it appears that on average, except for privately owned firms, industry as well as a group of privatized and public (state-owned) firms experienced a long-run decline in profitability in the overall post-1992 period. This decline is statistically significant both for the industry and privatized firms. The profitability did improve marginally for privatized firms in the first seven years after privatization (1992-98), but the increase is not statistically significant. Public sector firms' profitability decreased after 1992 but the differences between pre- and post-1992 values are not statistically significant. Interestingly, 
the profitability margin of the group of private firms was statistically significantly higher in the post-1992 period. These firms started earning higher returns immediately after the reforms and privatization (during 1992-98) and continued doing so in the subsequent 13 years too. Hence, it could be argued that a change of ownership did not make firms more profitable but perhaps some other factors could be responsible for the better performance of firms established and working under private ownership.

Similarly, Table 4 shows that except for public sector firms, net income efficiency improved in the overall post-1992 period, but the improvements are not statistically significant. This is true for the first seven years as well as the next 13 years except for privatized firms. Interestingly, privatized firms' income efficiency statistically significantly decreased during the longer postprivatization period (1999-2011) and the decline was quite substantial. Hence any improvement in efficiency for the group of privatized firms in the initial post-privatization honeymoon period was lost within a few years.

The Wilcoxon test shows that real median sales increased for the entire industry as well as for the group of private firms over the longer post-reform period as well as the period 1999-2011 and the increase is statistically significant too. For the overall industry and the group of private firms, most improvement came during the longer post-reform period (1999 to 2011). The increase for privatized firms is very marginal during the immediate period of reforms but is statistically significant nonetheless. Interestingly, privately owned firms experienced a marginal but a statistically significant decline during this period. For the group of firms that remained in the public 
sector until the time they were eventually privatized, there was a decline in output (real sales) over short as well as longer post-reform time periods. But this decline is not statistically significant.

Years of underinvestment under public ownership led to severe maintenance issues alongside limited production capacity. It was expected that new management would make substantial capital investment in upgrading technology and capacity addition. The test results contained in Table 4 show that for the overall post-reform period as well as for the immediate first seven years, the group of private and privatized firms experienced an increase in capital spending but the improvement is statistically significant only for the privatized firms. On average, privatized firms increased their capital investment spending from $-0.71 \%$ to $2.1 \%$ of their sales after privatization and this significant increase came immediately after privatization. Interestingly, the firms that were not privatized initially recorded a statistically insignificant decline in capital spending during this period. For the longer-run post-reform period (1999 to 2011), overall industry as well as the group of private and privatized firms experienced improvement in capital spending but statistical significance is observed only for the entire industry.

Based on this above simple financial analysis, we can conclude that for the group of privatized firms, except for capital expenditure, profitability, net income efficiency and real sales did not improve over the longer run of the post-broader reforms and change of ownership time period. Hence, the only positive outcome from the change of ownership appears to be a significant increase in capital expenditures perhaps due to the unavoidable replacement of old technology and production capacity expansion so that these firms could compete with larger already privately owned firms. Broadly speaking, these financial performance trends for the group of privatized 
firms are not generally similar to competitor private sector firms who have done well in terms of profitability, efficiency and output. But when privatized firms are compared with those firms that were not privatized in the first phase of the mass privatization programme, their performance does not appear to be inferior. However, this superior performance could have been due to sample selection bias, where more profitable and relatively efficient firms were privatized first.

\section{Table 4: Firms' financial performance evaluation}

\begin{tabular}{|c|c|c|c|c|c|c|c|c|c|c|}
\hline & \multirow{2}{*}{$\begin{array}{c}\begin{array}{c}\text { Pre- } \\
\text { reform } \\
\text { period }\end{array} \\
(1)\end{array}$} & \multicolumn{3}{|c|}{$\begin{array}{c}+20 \text { years } \\
\text { post-reform period }\end{array}$} & \multicolumn{3}{|c|}{$\begin{array}{c}+7 \text { years } \\
\text { post-reform period }\end{array}$} & \multicolumn{3}{|c|}{$\begin{array}{c}+13 \text { years } \\
\text { post-reform period }\end{array}$} \\
\hline & & (2) & (3) & (4) & (5) & (6) & (7) & (8) & (9) & $(10)$ \\
\hline & 1986- & 1992- & Z & Prob. & 1992- & Z & Prob. & 1999- & Z & Prob. \\
\hline \multicolumn{11}{|l|}{ Industry } \\
\hline Profitability & 11.508 & 4.834 & 4.949 & 0.000 & 7.6565 & 2.932 & 0.003 & 4.451 & 5.419 & 0.000 \\
\hline Net income efficiency & 0.022 & 0.055 & -0.822 & 0.411 & 0.053 & -0.610 & 0.542 & 0.063 & -0.830 & 0.407 \\
\hline Real sales & 15.514 & 21.764 & -4.096 & 0.000 & 18.721 & -1.535 & 0.125 & 24.219 & -4.996 & 0.000 \\
\hline Capital expenditure & -0.103 & -0.113 & -2.047 & 0.041 & -0.945 & -1.358 & 0.175 & 1.144 & -2.177 & 0.030 \\
\hline \multicolumn{11}{|l|}{ Privatized firms } \\
\hline Profitability & 7.655 & 4.805 & 2.625 & 0.009 & 8.873 & 0.762 & 0.446 & 3.333 & 3.728 & 0.000 \\
\hline Net income efficiency & 0.041 & 0.048 & 1.257 & 0.209 & 0.062 & -1.391 & 0.164 & 0.003 & 1.950 & 0.051 \\
\hline Real sales & 20.024 & 21.103 & -1.419 & 0.156 & 21.845 & -2.210 & 0.027 & 19.647 & -1.290 & 0.197 \\
\hline Capital expenditure & -0.707 & 2.069 & -1.708 & 0.088 & 1.781 & -1.711 & 0.087 & 2.546 & -1.340 & 0.180 \\
\hline \multicolumn{11}{|l|}{ Publicly owned firms } \\
\hline Profitability & 7.355 & 3.296 & 0.829 & 0.407 & 3.565 & 0.444 & 0.657 & 3.454 & 1.107 & 0.268 \\
\hline Net income efficiency & 0.069 & -0.020 & 0.999 & 0.318 & -0.019 & 1.050 & 0.294 & -0.015 & 0.530 & 0.596 \\
\hline Real sales & 21.783 & 16.064 & 0.510 & 0.610 & 16.920 & 0.370 & 0.712 & 15.990 & 0.530 & 0.596 \\
\hline Capital expenditure & 1.840 & -2.756 & 0.987 & 0.324 & -2.756 & 0.710 & 0.478 & -2.515 & 1.069 & 0.285 \\
\hline \multicolumn{11}{|l|}{ Privately owned firms } \\
\hline Profitability & 5.778 & 7.638 & 4.846 & 0.000 & 11.920 & 3.640 & 0.000 & 7.355 & 4.964 & 0.000 \\
\hline Net income efficiency & 0.021 & 0.095 & -1.147 & 0.251 & 0.086 & -1.239 & 0.216 & 0.085 & -1.037 & 0.300 \\
\hline Real sales & 18.279 & 22.624 & -4.267 & 0.000 & 17.440 & -2.249 & 0.025 & 24.542 & -4.721 & 0.000 \\
\hline Capital expenditure & -0.977 & 3.678 & 0.768 & 0.443 & 6.607 & 0.441 & 0.659 & 3.732 & 0.829 & 0.407 \\
\hline \multicolumn{11}{|c|}{$\begin{array}{l}\text { Notes: Columns } 1 \text { and } 2 \text { above present the median values for pre- and post-privatization periods. Before privatization covers the period between } 1986 \text { and } 1991 \text { and } \\
\text { after privatization covers the period between } 1993 \text { and } 2011 \text {. For the tests of the significance of median change, we used the Wilcoxon rank sum test (with its Z } \\
\text { statistics) as our principal statistic. The probability column shows the significance level for the null hypothesis that the difference between two median values is zero. } \\
\text { Ratios are calculated by using the following formulas: }\end{array}$} \\
\hline
\end{tabular}


Investigating the impact of broader reforms and privatization on the financial performance of other similar industries that experienced privatization

An interesting and sensible question in this regard, however, is: was this relatively disappointing profitability and efficiency performance of privatized firms compared to already privately owned firms limited to the cement industry or has it also been a widespread trend for all those other Pakistani manufacturing firms who have experienced privatization? More specifically, attributing bad or good financial performance purely to a change of ownership in the cement industry could be misleading for a variety of reasons, such as technology constraints, location disadvantages and local input/output market conditions and macroeconomic environment etc. To address these issues and for the sake of sensitivity analysis, we compare the cement industry's financial performance against other industries that had experienced a change of ownership alongside other broader reforms during almost the same time period. We assembled and analysed data on four other manufacturing industries - chemical, automobile, cooking oil and engineering - and subsequently compared the financial performance of these industries with our case study, the cement industry.

Similarly to the cement industry, we first computed financial ratios for the entire industry and then compared privatized firms with their peer groups from the public sector firms who were not privatized in 1991/92 for a variety of reasons, as well as with those that were set up under private ownerships and remained so, using the Wilcoxon test. For this exercise, we restrict our sample period and analysis to the first ten years of the post-reform and privatization period (1992-2001) due to significant operational, financial and time constraints in collecting and compiling such detailed historical financial data. Similarly, due to the heterogeneity in firm sizes across different 
industries and data availability issues, we modified some of our financial ratios discussed above. All these modifications were also applied to the cement industry to make a valid comparison.

Profitability in this sensitivity analysis exercise is measured by returns on sale, efficiency is measured by asset efficiency represented by firms' sales to asset ratio, capital expenditure ratio is measured by capital expenditure to total asset and output is measured by real sales value. Our final matching sample comprises 98 firms from the four Pakistani manufacturing industries mentioned above. These include 23 firms from the automobile industry (comprising 6 privatized, 9 stateowned and 8 private), 38 firms from the chemical industry (4 privatized, 12 state-owned and 22 private), 20 firms from the cooking oil industry (5 privatized, 10 state-owned and 5 private) and 17 firms from the engineering industry (comprising 2 privatized, 9 state-owned and 6 private sector firms). The post-privatization and broader reforms period is divided into two subperiods. The first period covers the initial impact comprising the first five years (1992-1996) and the second period covers the ten years from 1992 to 2001.

The estimates contained in Table 5 show that except for privatized firms in the automobile industry, firms belonging to all other four industries did not improve their profitability in the short or the long run of the post-reform period. In fact, they recorded a statistically significant decline in profitability. The significant improvement in the profitability recorded for the privatized automobile firms should also be looked at in the context of industry structure and market conditions. The automobile manufacturing firms have a clear market advantage due to the government protection policy of local manufacturing of vehicles due to import restrictions. The market is monopolized by a few firms and these firms have long been accused of exploiting their 
dominant position. Firms already set up in the private sector did relatively well over five and ten years in the post-reform and privatization period. Although improvement in profitability is not statistically significant it is better than in privatized and state-owned firms. Hence, this confirms that the disappointing profitability performance of privatized firms was not limited to cement manufacturers but was widespread.

The story concerning financial efficiency was very similar to that of profitability for the group of privatized firms. The privatized firms belonging to the cement, engineering and cooking oil industries experienced a statistically significant decline in efficiency over ten years in the postprivatization period. The group of privatized firms belonging to the chemical and automobile industry, however, witnessed an increase in efficiency over ten years but this increase is not statistically significantly different from the pre-privatization period. The group of private firms belonging to the automobile and chemical industries performed much better both in the short and longer time periods in contrast to firms from the cooking oil industry. Interestingly, state-owned firms belonging to the chemical industry did well in the short and the long run. Hence, based on the above analysis, relatively speaking, one can conclude that the group of privatized firms, irrespective of the industry they belonged to, did not do well in terms of efficiently using their resources during the post-privatization shorter and longer time periods.

For output measured by real sales value, except for the chemical industry, privatized firms in all other industries experienced a decline during the first five and ten years in the post-reform and privatization period. This decline is significant, though, only for the engineering and cooking oil industries. Interestingly, private firms, except for the automobile and cement industries, recorded 
a decrease in output (real sales). This decrease, in particular, is also statistically significant for the cooking oil and chemical industries. The increase for automobile firms over the shorter and longer time periods is an interesting one, as is the case for state-owned firms belonging to the chemical industry. Interestingly, for the automobile and cooking oil industries, a significant decline is recorded for the state-owned firms during the same time periods.

\section{Table 5: Comparative financial performance of manufacturing industry}

\begin{tabular}{|c|c|c|c|c|c|c|}
\hline & \multicolumn{2}{|c|}{ Privatized firms } & \multicolumn{2}{|c|}{ Privately owned firms } & \multicolumn{2}{|c|}{ Publicly owned firms } \\
\hline & $\begin{array}{c}+5 \text { years } \\
\text { post reforms }\end{array}$ & $\begin{array}{l}+10 \text { years } \\
\text { post reforms }\end{array}$ & $\begin{array}{c}+5 \text { years } \\
\text { post reforms }\end{array}$ & $\begin{array}{c}+10 \text { years } \\
\text { post reforms }\end{array}$ & $\begin{array}{c}+5 \text { years } \\
\text { post reforms }\end{array}$ & $\begin{array}{l}+10 \text { years } \\
\text { post reforms }\end{array}$ \\
\hline \multirow{3}{*}{$\begin{array}{l}\text { Cement industry } \\
\text { Automobile industry } \\
\text { Chemical industry } \\
\text { Engineering industry } \\
\text { Cooking oil industry }\end{array}$} & \multicolumn{6}{|c|}{ Profitability } \\
\hline & $\begin{array}{l}\text { increased } \\
\text { increased } \\
\text { declined } \\
\text { declined* } \\
\text { declined* }\end{array}$ & $\begin{array}{c}\text { declined }{ }^{*} \\
\text { increased* }^{*} \\
\text { declined }^{*} \\
\text { declined* } \\
\text { declined* }\end{array}$ & $\begin{array}{l}\text { increased* } \\
\text { Increased } \\
\text { Increased } \\
\text { declined } \\
\text { declined* }\end{array}$ & $\begin{array}{c}\text { declined } \\
\text { increased } \\
\text { increased } \\
\text { declined } \\
\text { declined }\end{array}$ & $\begin{array}{l}\text { declined } \\
\text { increased } \\
\text { declined } \\
\text { declined } \\
\text { declined* }\end{array}$ & $\begin{array}{l}\text { declined } \\
\text { increased } \\
\text { declined } \\
\text { declined } \\
\text { declined* }\end{array}$ \\
\hline & \multicolumn{6}{|c|}{ Asset efficiency } \\
\hline \multirow[t]{2}{*}{$\begin{array}{l}\text { Cement industry } \\
\text { Automobile industry } \\
\text { Chemical industry } \\
\text { Engineering industry } \\
\text { Cooking oil industry }\end{array}$} & $\begin{array}{l}\text { declined } \\
\text { declined } \\
\text { increased } \\
\text { declined* } \\
\text { declined }\end{array}$ & $\begin{array}{l}\text { declined* } \\
\text { increased } \\
\text { increased } \\
\text { declined* } \\
\text { declined* }\end{array}$ & $\begin{array}{l}\text { declined } \\
\text { increased* } \\
\text { increased* } \\
\text { increased } \\
\text { declined* }\end{array}$ & $\begin{array}{c}\text { declined* } \\
\text { increased* } \\
\text { increased* } \\
\text { increased } \\
\text { declined* }\end{array}$ & $\begin{array}{c}\text { declined } \\
\text { declined* } \\
\text { increased* } \\
\text { declined* } \\
\text { increased* }\end{array}$ & $\begin{array}{c}\text { increased } \\
\text { declined* } \\
\text { increased* } \\
\text { declined* } \\
\text { increased }\end{array}$ \\
\hline & \multicolumn{6}{|c|}{ Real sales } \\
\hline $\begin{array}{l}\text { Cement industry } \\
\text { Automobile industry } \\
\text { Chemical industry } \\
\text { Engineering industry } \\
\text { Cooking oil industry }\end{array}$ & $\begin{array}{l}\text { increased } \\
\text { declined } \\
\text { increased } \\
\text { declined* } \\
\text { declined* }\end{array}$ & $\begin{array}{l}\text { declined } \\
\text { declined } \\
\text { increased } \\
\text { declined* } \\
\text { declined* }\end{array}$ & $\begin{array}{c}\text { increased* } \\
\text { increased* } \\
\text { declined* } \\
\text { declined } \\
\text { declined* }\end{array}$ & $\begin{array}{c}\text { increased } \\
\text { increased* } \\
\text { declined* } \\
\text { declined } \\
\text { declined* }\end{array}$ & $\begin{array}{c}\text { declined } \\
\text { declined* } \\
\text { increased* } \\
\text { increased } \\
\text { declined* }\end{array}$ & $\begin{array}{c}\text { declined } \\
\text { declined* } \\
\text { increased* } \\
\text { increased } \\
\text { declined* }\end{array}$ \\
\hline & \multicolumn{6}{|c|}{ Capital expenditure } \\
\hline $\begin{array}{l}\text { Cement industry } \\
\text { Automobile industry } \\
\text { Chemical industry } \\
\text { Engineering industry } \\
\text { Cooking oil industry }\end{array}$ & $\begin{array}{l}\text { increased* } \\
\text { declined } \\
\text { increased } \\
\text { declined } \\
\text { increased* }\end{array}$ & $\begin{array}{l}\text { declined } \\
\text { declined } \\
\text { increased } \\
\text { declined* } \\
\text { increased* }\end{array}$ & $\begin{array}{l}\text { declined } \\
\text { declined } \\
\text { declined } \\
\text { increased } \\
\text { declined }\end{array}$ & $\begin{array}{l}\text { declined* } \\
\text { declined } \\
\text { declined } \\
\text { declined } \\
\text { declined }\end{array}$ & $\begin{array}{l}\text { increased } \\
\text { increased } \\
\text { declined } \\
\text { increased } \\
\text { declined }\end{array}$ & $\begin{array}{l}\text { declined } \\
\text { increased } \\
\text { declined } \\
\text { increased } \\
\text { declined }\end{array}$ \\
\hline
\end{tabular}

Notes: * indicates improvement/decline or no improvement compared to pre-reform period is statistically significant.

As far as the modified capital investment ratio is concerned, privatized firms from the cement industry improved their investment in the post-privatization short-run time period (first five years).

Similarly, in contrast to profitability and efficiency, firm investment in capacity additions and 
technology upgrades increased for the next ten years subsequent to reforms for the firms from the cooking oil industry that experienced a change of ownership from the public to the private sector. This increase is statistically significant too. There was, however, a completely different scenario for privatized engineering industry firms over a longer time period. Private firms in general did not invest more and, in fact, experienced a decline in almost all four industries over a shorter and longer time period. However, this decline is not statistically significant except for the cement industry over the ten-year post-reform period. For state-owned firms, there appears to be a mixed trend, but all those changes are statistically insignificant nonetheless.

Investigating the impact of broader reforms on the financial performance of those industries that did not experience privatization

To further isolate the long-run impact of broader reforms including change of ownership from industry-related factors, we computed the above-mentioned ratios and subsequently performed a Wilcox test to observe the impact of broader reforms on the financial performance of those industries that did not experience a change of ownership due to privatization. These two industries are energy and steel manufacturing. The results of this exercise are presented in Table 6. Starting with the profitability results, it is clear that for both industries, we are unable to find any statistically significant improvement or decline during the five- and ten-year post-reform periods. For the steel manufacturing firms, there is evidence of improvement but this was merely catching up from the downward trend (as the ratio is still negative).

The capital expenditure story is very similar where there is some evidence of improvement but not enough to make the change positive year on year. Interestingly, changes are statistically significant 
in most of the cases. Looking at the efficiency indicator, there is evidence of improvement during the immediate as well as the longer post-reform period but this improvement is not statistically significant. For real sales or output, again, there is evidence of increase during the immediate as well as the relatively longer post-reform period but these improvements are not statistically significant. Hence, broadly speaking, the post-reform financial performance outcomes for these two industries are not any better than the other five industries discussed above irrespective of the choice of indicator and the post-reform time periods.

Table 6: Financial performance of state-owned firms with no privatization effect

\begin{tabular}{|c|c|c|c|c|c|c|}
\hline & Period & Scenario & $\begin{array}{l}\text { Return on } \\
\text { sale }\end{array}$ & $\begin{array}{c}\text { Asset } \\
\text { efficiency }\end{array}$ & Output & $\begin{array}{c}\text { Capital } \\
\text { expenditure }\end{array}$ \\
\hline \multirow[t]{4}{*}{ Energy } & 1986-91 & Before & 2.11 & 121.09 & 9991.54 & -2.25 \\
\hline & 1992-96 & After & 1.03 & 133.73 & 11672.43 & -2.06 \\
\hline & & Z & 0.05 & -1.30 & -0.54 & -2.36 \\
\hline & & Prob. & 0.96 & 0.19 & 0.59 & 0.02 \\
\hline \multirow[t]{4}{*}{ Steel } & 1986-91 & Before & -13.06 & 29.38 & 257.00 & -0.95 \\
\hline & 1992-96 & After & 0.64 & 38.41 & 19297.68 & -1.22 \\
\hline & & Z & 0.21 & -0.75 & -0.48 & -2.28 \\
\hline & & Prob. & 0.83 & 0.45 & 0.63 & 0.02 \\
\hline \multirow[t]{4}{*}{ Energy } & 1986-91 & Before & 2.11 & 121.09 & 9991.54 & -2.25 \\
\hline & 1992-01 & After & 1.63 & 150.77 & 23169.99 & -1.90 \\
\hline & & Z & 1.16 & -0.06 & -0.35 & -2.05 \\
\hline & & Prob. & 0.25 & 0.95 & 0.73 & 0.04 \\
\hline \multirow[t]{4}{*}{ Steel } & 1986-91 & Before & -13.06 & 29.38 & 257.00 & -0.95 \\
\hline & 1992-01 & After & -3.61 & 38.33 & 14879.27 & -0.59 \\
\hline & & Z & -2.87 & 0.51 & -0.13 & -0.74 \\
\hline & & Prob. & 0.00 & 0.61 & 0.90 & 0.46 \\
\hline
\end{tabular}

Notes: return on sale $=(\text { net profit after tax/net sales })^{*} 100 ;$ return on assets $=\left(\right.$ net profit before tax/total assets) ${ }^{*} 100 ;$ asset efficiency $=\left(\right.$ net sales/total assets) ${ }^{* 100 ;}$ capital expenditure $=(($ operating fixed assets $[\mathrm{t}]$ - operating fixed assets $[\mathrm{t}-1]) /$ total assets $) * 100 ;$ output $=$ net sales $/(\mathrm{CP})$. Outlier removed.

\subsection{Productivity estimates}

Table 7 reports our empirical estimates for the Malmquist productivity index ( $\Delta$ Malm), efficiency changes $(\Delta \mathrm{Eff})$ and its components [pure efficiency change ( $\Delta$ PureEff) and scale efficiency $(\Delta$ Scale) $]$, technological change $(\Delta \mathrm{Tech})$ and its components (pure technical change $(\Delta \mathrm{PureTech})$ 
and changes in the scale of technology $(\Delta$ ScaleTech $))$. The Malmquist indices, their components and confidence intervals were computed using the FEAR software package with R developed by Wilson (2008).

By applying bootstrap procedures, we compute upper and lower confidence intervals. These confidence intervals are then used to determine the statistical significance of productivity estimates and its components. According to Simar and Wilson (1999), the sample variance of the normal Malmquist productivity values $\left\{\widehat{m}(b)_{i},(t, t+1)\right\}$ for $b=1, \ldots, B$ is $s^{2}(b)_{i}$ and the estimated mean square error (MSE) of biased corrected Malmquist productivity $\widehat{m} \_$corr $i,(t, t+1)$ is $4 s^{2}(b)$. Simar and Wilson argued that the 'original' estimates $\widehat{m}(\mathrm{~b})_{\mathrm{i}},(\mathrm{t}, \mathrm{t}+1)$ rather than the biased corrected estimates $\widehat{m}_{-}$corr,$(t, t+1)$ should be used if $s^{2}(b)_{i}>\frac{1}{3} \operatorname{bias}\left(\widehat{m}_{\mathrm{i}},(\mathrm{t}, \mathrm{t}+1)\right.$. In our case, this is true and we present our original productivity estimates in our presentation of results contained in Table 7 .

In the presentation of our productivity estimates, we first estimate and present productivity estimates for adjacent years and then the geometric means of different time periods encompassing the pre- and post-privatization and reforms period (similarly to financial analysis, the years 1987 to 1991 cover the pre-privatization period and 1992 onward post-privatization). The year 2007 was an exceptional year in Pakistan due to elections, political demonstrations, strikes and an overall political and economic instability; hence, we also calculate and report results by excluding the year 2007 from the post-privatization period. Again similarly to financial analysis, we also present these estimates for different ownership firms, such as public, private and privatized, to highlight the role of ownership in the management of resources. 


\subsubsection{Separating the short- and long-term impact of privatization on productivity}

Table 7 shows that industry as a whole recorded 2.8 per cent growth per annum (p.a.) during the period 1987-2011. Technological progress or innovation contributed mainly to this growth in productivity suggesting that productivity growth did not come from 'catch-up' but only from 'frontier shift'. The growth in technological progress was 3.3 per cent p.a. and the pure technical change seems to be the only source of improvement. The insignificant contribution of efficiency improvement is similar to that in our financial analysis and Saygili and Taymaz (2001), Rossi (2001) and Resende and Facanha (2002), who, while assessing the impact of privatization, were unable to find evidence that privatization improves firms' efficiency.

Table 7: Total factor productivity and its sources

\begin{tabular}{|c|c|c|c|c|c|c|c|}
\hline & \multirow{2}{*}{$\begin{array}{c}\text { Productivity change } \\
\Delta \text { Malm }\end{array}$} & \multicolumn{3}{|c|}{ Efficiency change } & \multicolumn{3}{|c|}{ Technical change } \\
\hline & & $\Delta \mathrm{Eff}$ & $\Delta$ PureEff & $\Delta$ Scale & $\Delta \mathrm{Tech}$ & $\Delta$ PureTech & $\Delta$ ScaleTech \\
\hline & \multicolumn{7}{|c|}{ Entire industry } \\
\hline 1987-2011 & 1.028 & 0.995 & 1.001 & 0.994 & 1.033 & 1.030 & 1.004 \\
\hline 1987-1991 & 0.993 & 0.998 & 0.996 & 1.002 & 0.996 & 0.990 & 1.004 \\
\hline $1992-2011$ & 1.037 & 0.995 & 1.003 & 0.992 & 1.042 & 1.040 & 1.004 \\
\hline $1992-2011^{a}$ & 1.058 & 0.991 & 1.000 & 0.991 & 1.067 & 1.058 & 1.007 \\
\hline 1992-1999 & 1.005 & 0.983 & 0.999 & 0984 & 1.021 & 1.016 & 1.005 \\
\hline \multirow[t]{2}{*}{$1999-2011^{a}$} & 1.096 & 1.002 & 1.011 & 0.991 & 1.094 & 1.081 & 1.009 \\
\hline & \multicolumn{7}{|c|}{ Privatized firms } \\
\hline 1987-2011 & 1.010 & 0.987 & 0.996 & 0.991 & 1.024 & 1.020 & 1.004 \\
\hline 1987-1991 & 0.991 & 0.995 & 0.995 & 1.000 & 0.995 & 0.994 & 1.001 \\
\hline $1992-2011$ & 1.022 & 0.986 & 0.998 & 0.989 & 1.036 & 1.027 & 1.007 \\
\hline $1992-2011^{a}$ & 1.040 & 0.982 & 0.992 & 0.990 & 1.059 & 1.044 & 1.009 \\
\hline 1992-1999 & 0.993 & 0.980 & 0.985 & 0.994 & 1.013 & 1.009 & 0.999 \\
\hline \multirow[t]{2}{*}{$1999-2011^{a}$} & 1.096 & 1.007 & 1.016 & 0.991 & 1.088 & 1.070 & 1.008 \\
\hline & \multicolumn{7}{|c|}{ Publicly owned firms } \\
\hline 1987-1999| & 1.007 & 0.979 & 1.003 & 0.976 & 1.028 & 1.012 & 1.013 \\
\hline 1987-1991 & 0.997 & 1.000 & 0.995 & 1.004 & 0.996 & 0.988 & 1.003 \\
\hline \multirow[t]{2}{*}{ 1992-1999 } & 1.016 & 0.965 & 1.010 & 0.955 & 1.052 & 1.029 & 1.020 \\
\hline & \multicolumn{7}{|c|}{ Privately owned firms } \\
\hline 1987-2011 & 1.047 & 1.003 & 1.005 & 0.998 & 1.044 & 1.048 & 0.999 \\
\hline 1987-1991 & 0.997 & 0.998 & 0.998 & 1.000 & 0.998 & 0.986 & 1.013 \\
\hline 1992-2011 & 1.047 & 1.000 & 1.004 & 0.996 & 1.046 & 1.050 & 0.999 \\
\hline $1992-2011^{a}$ & 1.065 & 0.996 & 1.002 & 0.994 & 1.070 & 1.067 & 1.004 \\
\hline 1992-1999 & 1.012 & 1.006 & 1.005 & 1.000 & 1.006 & 1.009 & 1.001 \\
\hline $1999-2011^{a}$ & 1.099 & 1.004 & 1.012 & 0.993 & 1.094 & 1.091 & 1.003 \\
\hline
\end{tabular}

Notes: a. Excluding 2007. Value of $\Delta \mathrm{M}$ greater (less) than 1 indicates increase (decrease) in productivity. Growth is calculated by deducting 1 from the values. 
By looking at the pre-privatization period (1987-1991), industry witnessed a 0.70 per cent p.a. decrease in productivity (represented by a 0.20 per cent efficiency drop and 0.40 per cent technological regress). Our results in pre-privatization, are very similar to Amess and Roberts (2007) who documented a 1 per cent decline in productivity in the pre-privatization period. In contrast to this, in the post-privatization periods, industry achieved 3.7 per cent growth p.a. during 1992-2011 with technological advancement being the sole contributor (4.2 per cent growth p.a.). By excluding the year 2007, we see even more impressive growth figures in the post-privatization period.

After dividing the post-privatization period into two further sub-periods, one for the initial impact of privatization (1992-1999) and the second for the relatively longer post-privatization and reforms period (1999 to 2011), we note that for the sub-period 1992-1999, industry does not show any productive progress. Any improvement in technological progress was offset by the decline in efficiency. Efficiency decline was primarily due to scale inefficiency and technological progress was achieved by pure technical change. But since 1999, industry has done exceptionally well, with productivity growth being 9.6 per cent p.a. and technological progress contributing 9.4 per cent. Hence, conclusions from the industry averages seem to lead us to believe that significant growth in post-privatization was achieved due to innovations in technology (technological advancement shifting the frontier) and to some extent driven by factor accumulation and possibly due to an increased management effort alongside significant capital investment in acquiring new advanced technology, replacing outdated production processes and significant capacity additions in the first few years of the post-reform/privatization period and subsequently. The estimates further show that the improvement in productivity would have been more if firms had not experienced a decline 
in scale efficiency due to suboptimal use of capacity after accumulating excess capacity between 1999 and 2011.

\subsubsection{Separating the short- and long-term impact of privatization on the productivity of different} ownership firms

Interestingly, in contrast to the nearly 3 per cent p.a. productivity growth in industry, privatized firms attained an overall growth of only 1 per cent p.a. during the sample period, mainly due to 2.4 per cent p.a. in technological progress despite a 1.3 per cent decline in efficiency. Rather disappointingly, these firms witnessed a decrease in efficiency, which is opposite to the general consensus that privatization improves efficiency. This decline was due to both contributors such as not operating at optimal level and not being able to catch the frontier. The decline, however, was minimum. These firms did not show any improvement under public sector ownership (19871991), but a 2.2 per cent growth p.a. after change of ownership during 1992-2011. The growth in productivity was achieved due to the technological development of 3.6 per cent p.a. despite an efficiency decrease of 1.4 per cent. These estimates are 4 per cent growth p.a. after excluding 2007 with an efficiency reduction of 1.8 per cent and technological progress of 5.9 per cent p.a. During a relatively longer post-reform period, these growth rates are 9.6 per cent p.a. with a technological progress contribution of 8.8 per cent. For the post-privatization sub-period (1992 to 1999), similarly to the industry average, the group of privatized firms did not show any improvement/decline in productivity. An improvement in the technological growth was offset by the decline in efficiency. The decline in efficiency was perhaps due to operating at suboptimal level due to demand conditions as well as an increase in production capacity. 
None of the firms that remained in the state ownership showed any improvement in productivity between 1986 and 1999. Improvement in technology was offset by the decline in efficiency. Improvement in technology was achieved through pure technological change as well as a change in the scale of technology. Efficiency decline was primarily due to a decrease in scale efficiency (operating at suboptimal level). In terms of sub-periods, firms under state ownership did not perform any better from 1987 to 1991. Interestingly, an impressive technological progress of more than 5 per cent was swallowed up by the efficiency decline due to operating at suboptimal level. Pure technical change and scale technical change contributed equally towards technical progress for these state-owned firms during 1992-99.

The discussion of privatized firms as well as those who remained under state ownership on their own after 1991/92 is important but a better conclusion can be drawn when these firms are compared with competitor firms operating in a similar economic and regulatory environment. As discussed before, firms that started as private enterprises and remained so during our sample period are good candidates for such comparison. Private firms in our sample achieved an impressive growth of 4.7 per cent p.a. during 1986 to 2011, primarily due to the contribution to growth by technological advancement (4.4 per cent). During the pre- reform period, no significant productivity growth was achieved, while in the post-privatization period, this group of firms recorded 4.7 per cent growth p.a. with the contribution of technological progress being 4.6 per cent (negligible efficiency increase). After excluding 2007, these estimates are 6.5 per cent growth p.a. with a 7.0 per cent p.a. technological progress contribution. These estimates are 9.9 per cent growth p.a. during 1999 to 2011 with technological progress of 9.4 per cent p.a. (no contribution from efficiency gains again). Any improvement in the catching up of frontier was offset due to not 
utilizing the available capacity efficiently. Hence we can conclude for this group of firms, which are similar to the privatized group, that growth in the post-privatization/deregulation period was achieved due to innovations and technological advancements and they were certainly better than state-owned (current and former) firms.

One of the main criticisms of productivity estimates derived from the DEA distance function has been that these estimates could be unreliable due to data outlier issues as well as the familiar convergence problem due to the low number of firms (decision-making units (DMUs in DEA literature)). We understand and recognize the impact of these two issues on our productivity estimates given the fact that our productivity estimate conclusions appear to be completely different compared to financial analysis. Hence, as a sensitivity analysis, we also used a parametric method in estimating production function using the same inputs and output. These parameter estimates are subsequently used to drive productivity estimates for the entire industry.

These parametric method based productivity estimates stratified by different ownerships are presented in Appendix A. Ignoring the magnitudes of the productivity growth rates, the qualitative conclusions remain the same as discussed above, thereby confirming the validity of our productivity estimates and related pre- and post-reform and privatization conclusions. In an effort to obtain more understanding and robustness of our cement industry total factor productivity estimates and its components, we carried out further sensitivity analysis. The outcomes of this exercise are presented and discussed in the following subsection. 


\subsubsection{Comparison of cement industry productivity estimates and conclusions with other industries}

An interesting question could be that whether improvement in productivity in the cement industry was limited to one particular capital-intensive industry such as cement manufacturing or it was widespread as a result of the broader reforms including privatization. Alternatively, was the long run improvement in the cement industry productivity due to broader reforms including privatization or some other factors such as economic conditions, political environment and industrial activity etc.? The technical progress accomplished by the cement industry could have been as a result of compulsion in existing firms to make investment in technology upgrades after the transfer of ownership and capacity additions due to rising competition levels or the entry of new firms that would normally opt for acquiring new, relatively superior technology to compete with already established firms. By compiling data on the same inputs and output, we estimated similar DEA distance functions to those mentioned in the methodology section and then subsequently computed productivity estimates and its components (sources). Similarly to financial performance analysis, we focus on four industries (automobile, chemical, engineering and cooking oil). In the following, we evaluate these estimates of total factor productivity and its components for all four industries as well as by partitioning the sample into state owned, privatized and privately owned firms.

The productivity estimates presented in Table 8 indicate that, except for smaller-size and less capital-intensive industries such as cooking oil, all the other three industries experienced no improvement in productivity and in fact a decrease over five as well as ten years in the post-reform and privatization time period. This decline in productivity is also established after dividing the sample firms into different ownerships such as public, privatized and private. Interestingly, in the 
industry where there is evidence of significant productivity gains ( $7 \%$ p.a. for cooking oil), in complete contrast to the cement industry, improvement in productivity has been as a result of the catching up of the efficiency frontier (efficiency improvement) rather than the shifting of the frontier (technological progress). In fact, this industry experienced a technological regress over this ten-years post-reform period.

Table 8: Comparative productivity growth of the manufacturing industry firms

\begin{tabular}{|c|c|c|c|c|c|c|c|}
\hline & \multirow{2}{*}{$\begin{array}{c}\text { Productivity change } \\
\Delta \text { Malm }\end{array}$} & \multicolumn{3}{|c|}{ Efficiency change } & \multicolumn{3}{|c|}{ Technical change } \\
\hline & & $\Delta \mathrm{Eff}$ & $\Delta$ PureEff & $\Delta$ Scale & $\Delta \mathrm{Tech}$ & $\Delta$ PureTech & $\Delta$ ScaleTech \\
\hline & \multicolumn{7}{|c|}{ Automobile industry } \\
\hline $\begin{array}{l}\text { Pre reforms } \\
+5 \text { years post reforms } \\
+10 \text { years post reforms }\end{array}$ & $\begin{array}{l}1.00 \\
0.96 \\
0.98\end{array}$ & $\begin{array}{l}1.00 \\
1.02 \\
1.00\end{array}$ & $\begin{array}{l}1.00 \\
1.00 \\
1.00\end{array}$ & $\begin{array}{l}1.00 \\
1.00 \\
1.00\end{array}$ & $\begin{array}{l}1.02 \\
0.89 \\
0.95\end{array}$ & $\begin{array}{l}1.02 \\
0.89 \\
0.96\end{array}$ & $\begin{array}{l}1.00 \\
0.99 \\
1.00\end{array}$ \\
\hline+10 years post reforms & \multicolumn{7}{|c|}{ Chemical industry } \\
\hline $\begin{array}{l}\text { Pre reforms } \\
+5 \text { years post reforms } \\
+10 \text { years post reforms }\end{array}$ & $\begin{array}{l}1.00 \\
0.99 \\
0.97\end{array}$ & $\begin{array}{l}1.01 \\
1.07 \\
1.02\end{array}$ & $\begin{array}{l}1.00 \\
1.07 \\
1.00\end{array}$ & $\begin{array}{l}1.00 \\
1.00 \\
1.00\end{array}$ & $\begin{array}{l}1.00 \\
0.92 \\
0.97\end{array}$ & $\begin{array}{l}1.02 \\
0.91 \\
0.97\end{array}$ & $\begin{array}{l}1.00 \\
1.00 \\
1.00\end{array}$ \\
\hline+10 years post reforms & \multicolumn{7}{|c|}{ Engineering industry } \\
\hline $\begin{array}{l}\text { Pre reforms } \\
+5 \text { years post reforms } \\
+10 \text { years post reforms }\end{array}$ & $\begin{array}{l}1.01 \\
0.98 \\
0.97\end{array}$ & $\begin{array}{l}1.00 \\
1.00 \\
1.00\end{array}$ & $\begin{array}{l}1.00 \\
1.00 \\
1.00\end{array}$ & $\begin{array}{l}1.00 \\
1.00 \\
1.00\end{array}$ & $\begin{array}{l}1.09 \\
0.90 \\
0.94\end{array}$ & $\begin{array}{l}1.01 \\
0.89 \\
0.92\end{array}$ & $\begin{array}{l}1.00 \\
1.00 \\
1.00\end{array}$ \\
\hline+10 years post reforms & \multicolumn{7}{|c|}{ Cooking oil industry } \\
\hline Pre reforms & 0.93 & 1.00 & 1.01 & 1.01 & 0.99 & 1.02 & 0.99 \\
\hline+5 years post reforms & 1.07 & 1.15 & 1.11 & 1.00 & 0.89 & 0.89 & 0.99 \\
\hline \multirow[t]{2}{*}{+10 years post reforms } & 1.07 & 1.11 & 1.10 & 1.00 & 0.94 & 0.93 & 0.99 \\
\hline & \multicolumn{7}{|c|}{ Privatized firms only } \\
\hline Pre reforms & 0.98 & 1.00 & 1.00 & 1.00 & 0.99 & 1.00 & 0.99 \\
\hline+5 years post reforms & 0.95 & 1.05 & 1.00 & 1.00 & 0.89 & 0.90 & 1.00 \\
\hline \multirow[t]{2}{*}{+10 years post reforms } & 0.99 & 1.03 & 1.00 & 1.00 & 0.95 & 0.95 & 1.00 \\
\hline & \multicolumn{7}{|c|}{ Privately owned firms only } \\
\hline Pre reforms & 1.00 & 1.00 & 1.00 & 1.00 & 1.02 & 1.02 & 1.00 \\
\hline+5 years post reforms & 0.99 & 1.06 & 1.05 & 1.00 & 0.90 & 0.91 & 1.00 \\
\hline \multirow[t]{2}{*}{+10 years post reforms } & 0.99 & 1.00 & 1.00 & 1.00 & 0.96 & 0.96 & 1.00 \\
\hline & \multicolumn{7}{|c|}{ State-owned firms only } \\
\hline Pre reforms & 0.98 & 1.00 & 1.00 & 1.00 & 0.99 & 1.00 & 0.99 \\
\hline+5 years post reforms & 0.96 & 0.99 & 1.00 & 1.00 & 0.95 & 0.92 & 1.00 \\
\hline+10 years post reforms & 0.98 & 1.00 & 0.98 & 1.00 & 1.00 & 0.95 & 1.00 \\
\hline
\end{tabular}

Notes: Sample comprises 54 manufacturing firms.

Efficiency improvement is also confirmed for the sample of private and privatized firms. Both these groups of firms also experienced negative technical change. Rather disappointingly, this negative technical change has been common for all industries and ownership types (current and 
former, public and private). As a result, the gains in efficiency were offset by a decline in technology particularly for two industries (chemical and automobile), while for the engineering industry, pure technological regress caused the decline in productivity.

Hence, when the cement industry productivity growth is evaluated in comparison to five other similar industries from the manufacturing sector, it could be argued that except for the cooking oil industry, the cement industry has done well in the sense that significant technology upgrades have led to technological progress for privatized as well as private sector firms over a longer post reforms and privatization time period. But it is also true that attributing this productivity growth and technological progress to broader reform could be a bit misleading because we have observed, at least for three out of five industries, that industry did not make any progress in productivity growth despite going through similar types of reforms at the same time (early and mid-1990s). In the following discussion comprising qualitative analysis of the cement industry productivity estimates and subsequent regression analysis, we discuss the role of the initial conditions at the time of privatization and thereafter as well as the firms' specific factors and economic working environments to observe the net effect of broader reforms and privatization for our main case study.

\subsubsection{Further explanation of cement industry productivity growth}

In an effort to further investigate the reason behind the significant improvement in productivity for the group of private and privatized firms, we link these estimates to firm-specific and industry and economic changes subsequent to broader and regulatory reforms. More specifically, these factors include total production capacity, ownership type, profitability, investment, export, demand condition measured by capacity utilization, financial burden and its impact approximated by 
financial expenses and size of the firm etc. We first discuss the role of these factors qualitatively and subsequently run regression and make inferences.

\subsubsection{Qualitative explanation of cement producers' productivity performance}

In an effort to further understand specifically what cement producers did in terms of qualitative adjustments immediately after reforms and change of ownership that led to better performance, we conducted a comprehensive review of abstracts of the firm's annual report section of director reports related to all those firms of different industries discussed above. We also conducted interviews specifically with cement producers' association representatives. The outcome of this exercise could be summerised into four important qualitative adjustments made immediately after reforms including a change of ownership which led to the better performance of cement producing firms compared to other manufacturing firms discussed above.

\section{Changes in human resource management practices}

Prior to reforms and change of ownership, employees in state-owned firms enjoyed excessive holidays, less working hours and extraordinary other benefits such as leave of absence, medical facilities, holidays, and pensions. The new management of the privatized firms of the cement industry in particular got rid of excessive benefits, introduced competitive process in hiring and firing, and re-employed more productive and efficient employees who opted for voluntary early retirement before the transfer of ownership. Interestingly, contrary to broader claims that privatization reduces employment, privatized firms employed more workers after initial adjustments. The growth rate of the number of workers remained at $1.35 \%$ per annum for privatized firms during 1998 to 2011 compared to $-3.85 \%$ for publically owned firms after 1998 . 
The growth rate in the monthly wage rate was $6.2 \%$ and $-1.3 \%$ for privatized and public owned firms during this time period. Hence, the quality of workers became important subsequent to change of ownership. These policies played a dual role by first lowering the cost of production, and second introducing competition among employees for job protection.

\section{Reducing the excessive bargaining power of workers by labour unions}

Firms under public ownership had to endure excessive and unnecessary pressure from labour unions. This resulted in less than optimal operating days resulting in higher average cost. Cement producers of privatized firms in particular paid greater attention to this issue and labour union pressure was minimalized significantly as well as offering monetary incentives and perks to more productive employees. Overall management-labour relations remained fairly stable with the exception of two cases. Public sector employees remained absent from work on the pretext of a bad security situation. But after the change of ownership and reforms, this all changed. Employees remained reluctant to take days off due to the worry that they would not be paid after the union pressure had been reduced significantly. This led to record working days and longer working hours. Furthermore, poor law \& order conditions in the country impacted all businesses in terms of operating days but firms under public ownerships were hit hard due to job security. Compared to cement producers, for the other industries we evaluated above, we do not observe such significant curtailments in union pressure and subsequent record working days.

\section{Maintenance, modernization and rehabilitation of production plants}

Firms operating under public ownership neglected the routine repair and maintenance services for years resulting in lower capacity utilization, a reduction in operating days and a 
postponement in committed supplies. The new management scheduled routine maintenance on a priority basis. The price war in particular in the cement industry compared to other industries mentioned above led to an urgent need to a technology upgrade for ex public sector firms in particular. Freedom in setting up prices on the other hand resulted in better profitability and thus helped firms to opt for Building, Modernization and Rehabilitation (BMR) of existing old machinery. Two of the privatized firms in fact implemented BMR immediately after transfer of ownership. The subsequent results showed that under BMR programs, firms achieved cost efficiency advantages as well as higher operating days.

\section{Focus on inventory and working capital management}

The better access to inputs source and superior management of input-output inventory stocks to seek windfall gains in a period of uncertain demand, could be vital for efficiency and productivity improvement. The availability of sufficient working capital under private ownership is important due to the fact that private sector firms do not enjoy default protection in particular compared to state owned enterprises who enjoys such facility. The analysis of working capital stocks of the privatized cement producer firms clearly indicates that it improved immediately after change of ownership. This ensured that the new owners could achieve input at more competitive prices by negotiating with suppliers, at the time when publically owned firms were locked into supply contracts with other state-owned institutions and corporations. This in particular is truer for cement producer firms where inputs purchase is more in bulks compared to cooking oil, and ceramics etc. 
A univariate analysis to further understand the cement industry findings

A cursory look at Table 9 reveals some interesting facts. Starting with privatized firms, only three out of ten firms were in the top ten of outstanding performers in terms of productivity growth. Hence, as discussed above, change of ownership per se was not the significant determinant for the higher productivity growth reported and discussed before. The profitability and productivity relationship shows that five out of the top ten better performing firms were also more profitable. Hence, this indicates a relatively weak relationship between these two variables. Similarly, the six out of ten worst performing firms were those that have a high capital investment, indicating a negative relationship. Exporting status does not translate into better performance (excluding exceptional cases of two firms with more than a $15 \%$ share of sale from export receipts). There appears to be a weak relationship between capacity utilization and productivity growth. The estimates show that five out of the ten top performing firms have high capacity utilization.

Similarly, similar could be said of the relationship between the burden of financial expenses and productivity growth. It appears that five out of the top ten performing firms also have higher financial expenses relative to their total sales. Figures presented in the table reveal a strong positive relationship between cement demand and productivity performance. It appears that seven out of top ten better performing firms also sold a higher quantity of cement during the sample period than other competitor firms. The size of the firm approximated by the production capacity reveals that the six firms that have the highest current production capacity were among the bottom ten performers, thereby confirming the negative relation between productivity and size of the firm. We discuss the role of some of these factors in determining the firms' productivity growth in 
greater detail and subsequently model the determinants of productivity using a regression model in the next subsection below.

Table 9: Exploring interactions between firm-related factors and productivity

\begin{tabular}{|c|c|c|c|c|c|c|c|c|c|c|}
\hline Firms & $\begin{array}{l}\text { Average } \\
\text { productivity } \\
\text { growth } \\
(\Delta \mathrm{M})\end{array}$ & $\begin{array}{c}\text { Rank } \\
\text { of } \\
\Delta \mathrm{M}\end{array}$ & $\begin{array}{c}\text { Current } \\
\text { capacity } \\
\text { (last } \\
\text { year } \\
\text { of } \\
\text { sample) }\end{array}$ & $\begin{array}{c}\text { Current } \\
\text { ownership }\end{array}$ & $\begin{array}{l}\text { Profitability } \\
\text { (ROA) }\end{array}$ & $\begin{array}{c}\text { Capital } \\
\text { investment/ } \\
\text { total sales }\end{array}$ & $\begin{array}{c}\text { Export } \\
\text { sales } \\
\text { as a } \% \\
\text { of } \\
\text { total } \\
\text { sales }\end{array}$ & $\begin{array}{c}\text { Capacity } \\
\text { utilization }\end{array}$ & $\begin{array}{c}\text { Financial } \\
\text { expenses } \\
\text { as a } \% \\
\text { of } \\
\text { total } \\
\text { sales }\end{array}$ & $\begin{array}{c}\text { Cement } \\
\text { sales } \\
\text { quantity }\end{array}$ \\
\hline & (2) & (3) & (4) & (5) & (6) & (7) & (8) & (9) & (10) & (11) \\
\hline Associated & 1.043 & 7 & 6.31 & Privatized & 0.038 & 0.742 & 0.000 & 0.758 & 4.234 & 6.27 \\
\hline Zeal Pak & 0.989 & 19 & 17.55 & Privatized & 0.026 & 0.126 & 0.114 & 0.508 & 5.357 & 4.92 \\
\hline Maple Leaf & 1.029 & 12 & 36.90 & Privatized & 0.163 & 0.389 & 4.748 & 0.849 & 6.553 & 10.87 \\
\hline Javedan & 0.991 & 18 & 6.00 & Privatized & 0.076 & 0.280 & 0.272 & 0.652 & 6.512 & 4.10 \\
\hline Gharibwal & 0.965 & 20 & 20.10 & Privatized & 0.095 & 0.444 & 1.409 & 0.819 & 4.869 & 5.02 \\
\hline Mustehkam & 1.023 & 14 & 57.00 & Privatized & 0.097 & 0.088 & 0.327 & 0.823 & 4.396 & 6.07 \\
\hline Thatta & 1.043 & 7 & 4.50 & Privatized & 0.076 & -0.065 & 4.881 & 0.825 & 9.542 & 3.04 \\
\hline Kohat & 1.038 & 10 & 26.85 & Privatized & 0.161 & 0.146 & 6.299 & 0.766 & 4.875 & 4.51 \\
\hline Dandot & 1.007 & 15 & 5.04 & Privatized & 0.049 & 0.110 & 0.103 & 0.861 & 10.248 & 3.20 \\
\hline D.G. Khan & 1.025 & 13 & 40.20 & Privatized & 0.123 & 0.284 & 4.635 & 0.913 & 6.783 & 15.82 \\
\hline Pakland/Dewan & 1.045 & 6 & 29.40 & Private & 0.228 & 0.471 & 1.617 & 0.904 & 7.500 & 5.72 \\
\hline Cherat & 1.032 & 11 & 6.49 & Private & 0.155 & 0.071 & 9.177 & 0.961 & 3.927 & 6.31 \\
\hline Dadabhoy & 0.999 & 16 & 5.98 & Private & 0.169 & 0.319 & 1.457 & 0.854 & 11.221 & 3.70 \\
\hline Attock & 1.075 & 4 & 17.10 & Private & 0.268 & 0.128 & 9.595 & 0.902 & 0.867 & 11.26 \\
\hline Essa & 0.995 & 17 & 4.05 & Private & 0.061 & 0.419 & 11.487 & 0.787 & 6.174 & 2.72 \\
\hline Fecto & 1.057 & 5 & 7.80 & Private & 0.137 & 0.003 & 6.029 & 0.881 & 2.721 & 6.15 \\
\hline Fauji & 1.094 & 3 & 10.47 & Private & 0.097 & 0.333 & 9.629 & 0.846 & 12.302 & 8.97 \\
\hline Lucky & 1.104 & 2 & 38.87 & Private & 0.126 & 0.272 & 17.281 & 0.612 & 2.576 & 26.86 \\
\hline Pioneer & 1.043 & 7 & 11.86 & Private & 0.057 & 0.132 & 6.374 & 0.696 & 8.714 & 8.03 \\
\hline Chakwal & 1.179 & 1 & 24.00 & Private & 0.056 & -0.072 & 25.080 & 0.815 & 11.842 & 21.02 \\
\hline
\end{tabular}

8.2.4.2. Modelling the determinants of total factor productivity growth and its sources (multivariate analysis)

The univariate analysis presented above does not control for factors that could have jointly impacted on the firms' productivity. The productivity of the firms could improve/decline due to a variety of factors alongside change of ownership and broader reforms. The main aim of this section is to jointly empirically evaluate the impact of individual firm-specific factors, as well as temporal changes in the firms' operating and economic environment, on firms' productive performance 
discussed individually in the previous section. Firm-specific variables include profitability, capacity utilization, share of financial expenses in total revenues, size of the firm measured by the production capacity, share of export sales in total volume of sales, firm leverage ratio and ratio of capital investment to sales (level and square).

To take into account local and national demand conditions, we introduce the quantity of cement dispatched/sold, estimated population size of the country and public investment as a percentage of GDP. The significance of investment by the government for the cement industry is extremely important due to a low and decreasing investment in the private sector since Pakistan joined the war on terror. To account for the role of international macroeconomic activity, we introduce foreign remittances as a percentage of GDP. To observe the impact of change of ownership, we use a dummy variable privatized equal to ' 1 ' after transfer of ownership and zero for state ownership status. Our final regression model with productivity $(y)$ for firm $i$ in year $t$ takes the following form:

$$
\begin{aligned}
& y_{i t}=\beta_{1} * \text { profitability }_{i t}+\beta_{2} * \text { capital expenditure } \text { fit }_{i}+\beta_{3} \\
& * \text { square of capital expenditure }{ }_{i t}+\beta_{4} * \text { privatized }+\beta_{5} * \text { export share }_{i t} \\
& +\beta_{6} * \text { capacity utilization }_{i t}+\beta_{7} * \text { financial expenses }_{i t}+\beta_{8} * \text { firm size }_{i t} \\
& +\beta_{9} * \text { leverge }_{i t}+\beta_{10} * \text { demand }_{i t}+\beta_{11} * \text { population }_{t}+\beta_{12} \\
& * \text { public investment }_{t}+\beta_{13} * \text { foreign remittances } \text { for }_{t}+\varepsilon_{i t}
\end{aligned}
$$

As discussed in the methodology section, Malmquist productivity estimates in our case are estimated by using different distance functions derived by the DEA estimator. Simar and Wilson 
(2007) pointed out that these estimates could suffer from serial correlation. Hence, the estimation of the above specified model by standard techniques such as OLS method, censored regression or panel data regression has been proven to be inappropriate (see Simar and Wilson's (2007) study in this regard). By following Brissimis et al. (2008) alongside others, we use Simar and Wilson's (2007) bootstrapped estimator to carry out valid statistical inferences on regression estimates.

We are mindful of the fact that some of the above independent variables in equation (3) could be endogenously determined and hence not considering this adequately could lead to less robust estimates. We tested for each of the above regressors for endogeneity and concluded that profitability was indeed an endogenously determined variable. We followed Brissimis et al.'s (2008) methodology to address the issue of endogeneity. Subsequently, we ran a series of regressions with different specifications of the above model. For the sake of comparison, we also report regression results based on panel data random effect estimates alongside endogeneitycorrected Simar and Wilson (2007) bootstrapped estimates ${ }^{2}$.

The regression coefficient of profitability in Table 10 does not suggest that all those highly profitable firms are necessarily more productive too. It could be that those firms that are able to realize high profitability would be able to spend money from internal and external sources on technology upgrades and R\&D to boost future productivity and could in fact achieve technological progress. But a lack of efficient management of the resources at hand may not have led to an

\footnotetext{
${ }^{2}$ For further technical details and estimation procedure, please see Simar and Wilson (2007) and Brissimis et al. (2008).
} 
improvement in efficiency and this in turn would not translate into an improved overall productivity level.

Bansak et al. (2007) investigated the relationship between technology, capital spending and capacity utilization and concluded that technological change resulted in a decrease in capacity utilization in the USA manufacturing industry. Our measure of capital expenditure is the difference between current year operating fixed assets, which predominantly includes value of lands, equipment and machinery compared to previous years deflated by total sales of the current year. It is true that since 2004, significant investment has been made in the upgrading of technology and capacity additions and privatized firms have taken the lead in this context. It is clear from the regression coefficient attached to the variable privatized that change of ownership alone may not be sufficient to improve the factor productivity. The privatized regression coefficient is insignificant irrespective of specification or the method of estimating the regression parameters. The analysis performed in the previous section showed that out of the top five firms that added the highest production capacity, only one was among the top five performers. Hence, it is not surprising that we have a statistically significant negative coefficient of capital expenditure and the relation is robust with respect to different specifications.

The impact of a rising burden of financial expenses on firms' efforts to improve productivity is evident from the positive and statistically significant coefficient attached to this variable. It appears that significant capacity additions during our sample period by various firms may have been, in part, financed by bank loans and it would be expected that firms use resources at hand effectively 
to achieve maximum output. This is expected, given the fact that the improvement in productivity estimates as discussed above was as a result of new technology and innovation.

The size of the firms could serve as a proxy for market power as well as potential realization of economies of scale. We have concluded above that an improvement in productivity was attributed to positive technical change. Hence, we believe that size of the firm does indeed indicate local market power. The negative signs indicate that a higher value of firm size reduces productivity and technical progress. This negative relation is similar to Aghion et al. (2002), who surveyed firms in 25 transitional economies and found that competitive pressure enhances the performance of new as well as old firms. Total cement dispatches could be treated as a proxy for local demand and regional market power due to high transportation cost in the exporting of cement from one area to another. A statistically significantly positive coefficient attached to this variable confirms the positive demand side effect. Similarly, our regression results also indicate that a rising population helps to improve productivity due to, perhaps, an increase in product demand leading to higher capacity utilization.

Finally, we ran the above regression with efficiency and technical change as dependent variable on almost the same variable. Appendix B contains these regression coefficients, which shows that broadly speaking, the sign and significance are similar to the productivity estimate coefficients reported in Table 10, with few exceptions. Similarly to productivity growth, firms' profitability is not linked to technical change. Firms' capital investment and size negatively impacts on both efficiency and technical progress. For efficiency, this coefficient is insignificant, though. Financial burden measured by financial expenditure, demand conditions and population all positively 
contribute to technical progress, efficiency and total factor productivity. For population, though, in contrast to productivity and technical change, the regression coefficient for efficiency is statistically insignificant.

Table 10: Determinants of productivity change

\begin{tabular}{|c|c|c|c|c|c|c|c|c|}
\hline & \multicolumn{2}{|c|}{ (1) } & \multicolumn{2}{|c|}{$(2)$} & \multicolumn{2}{|c|}{ (3) } & \multicolumn{2}{|c|}{ (4) } \\
\hline & $\hat{\beta}$ & se & $\hat{\beta}$ & se & $\hat{\beta}$ & se & $\hat{\beta}$ & se \\
\hline \multicolumn{9}{|c|}{ 1. Panel data random effect estimates } \\
\hline Profitability $^{a}$ & 0.1148 & 0.0819 & 0.1145 & 0.0813 & 0.1147 & 0.0809 & & \\
\hline Capital expenditure ${ }^{b}$ & $-0.0805^{* * *}$ & 0.0296 & $-0.0806 * * *$ & 0.0295 & $-0.0499 * * *$ & 0.0156 & $-0.0517 * * *$ & 0.0157 \\
\hline Capital expenditure ${ }^{\mathrm{C}}$ & 0.0084 & 0.0071 & 0.0085 & 0.0070 & & & & \\
\hline Privatized $^{d}$ & -0.0171 & 0.0242 & -0.0172 & 0.0241 & -0.0153 & 0.0239 & & \\
\hline Export sale share ${ }^{e}$ & -0.0005 & 0.0014 & -0.0005 & 0.0014 & & & & \\
\hline Capacity utilization ${ }^{f}$ & -0.0032 & 0.0905 & & & -0.0088 & 0.0903 & 0.0149 & 0.0924 \\
\hline Financial expenses ${ }^{g}$ & $0.0028^{*}$ & 0.0016 & $0.0028 *$ & 0.0015 & $0.0031 * *$ & 0.0015 & $0.0029 *$ & 0.0015 \\
\hline Firm size ${ }^{h}$ & -0.0483 & 0.0525 & -0.0468 & 0.0313 & -0.0453 & 0.0523 & -0.0503 & 0.0521 \\
\hline Leverage $^{i}$ & 0.0030 & 0.0021 & 0.0030 & 0.0021 & 0.0032 & 0.0021 & & \\
\hline Demand $^{j}$ & 0.0672 & 0.0511 & $0.0657^{* *}$ & 0.0285 & 0.0635 & 0.0505 & 0.0701 & 0.0503 \\
\hline Population k & $0.0018^{* *}$ & 0.0008 & $0.0019 * *$ & 0.0008 & $0.0016^{* *}$ & 0.0007 & 0.0001 & 0.0015 \\
\hline Public investment ${ }^{\prime}$ & & & & & & & -0.0101 & 0.0135 \\
\hline Foreign remittances ${ }^{m}$ & & & & & & & -0.0121 & 0.0188 \\
\hline \multicolumn{9}{|c|}{ 2. Simar and Wilson (2007) bootstrapped estimates } \\
\hline Profitability ${ }^{a}$ & $0.0385^{n}$ & 0.1528 & $0.0309^{n}$ & 0.1540 & $0.0337^{n}$ & 0.1478 & & \\
\hline Capital expenditure ${ }^{b}$ & $-0.0841 * * *$ & 0.0297 & $-0.0851 * * *$ & 0.0296 & $-0.0521 * * *$ & 0.0159 & $-0.0536 * * *$ & 0.0158 \\
\hline Capital expenditure ${ }^{c}$ & 0.0089 & 0.0070 & 0.0090 & 0.0070 & & & & \\
\hline Privatized $^{d}$ & -0.0169 & 0.0240 & -0.0188 & 0.0241 & -0.0142 & 0.0237 & & \\
\hline Export sale share ${ }^{\mathrm{e}}$ & -0.0007 & 0.0013 & -0.0011 & 0.0017 & & & & \\
\hline Capacity utilization ${ }^{f}$ & -0.0299 & 0.0727 & & & -0.0498 & 0.0702 & -0.0556 & 0.0711 \\
\hline Financial expenses $\mathrm{g}$ & $0.0030 * *$ & 0.0015 & $0.0032^{* *}$ & 0.0015 & $0.0034^{* *}$ & 0.0015 & $0.0030 * *$ & 0.0015 \\
\hline Firm size ${ }^{h}$ & $-0.0795^{* * *}$ & 0.0285 & $-0.0705^{* * *}$ & 0.0241 & $-0.0871 * * *$ & 0.0255 & $-0.0958 * * *$ & 0.0365 \\
\hline Leverage $^{i}$ & 0.0029 & 0.0021 & 0.0029 & 0.0021 & 0.0033 & 0.0021 & & \\
\hline Demand $^{j}$ & $0.1002^{* * *}$ & 0.0219 & $0.0920 * * *$ & 0.0169 & $0.1072 * * *$ & 0.0185 & $0.1161 * * *$ & 0.0335 \\
\hline Population ${ }^{k}$ & $0.0019 * *$ & 0.0008 & $0.0021^{* * *}$ & 0.0008 & $0.0016^{* *}$ & 0.0007 & 0.0013 & 0.0011 \\
\hline Public investment & & & & & & & 0.0003 & 0.0102 \\
\hline Foreign remittances ${ }^{m}$ & & & & & & & -0.0071 & 0.0182 \\
\hline \multicolumn{9}{|c|}{ 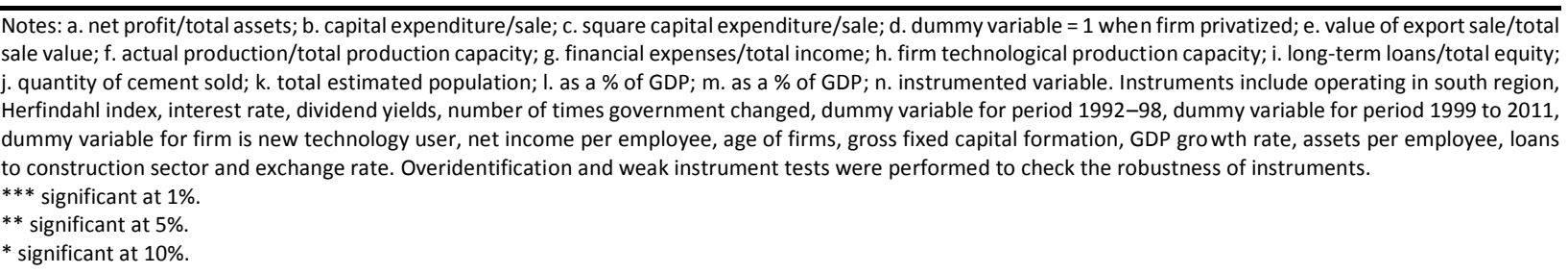 } \\
\hline
\end{tabular}




\section{Conclusions}

The main objective of this study was to observe the long-run impact of broader reforms including privatization on firms' financial and operational performance. We assembled historical financial and operational data on the Pakistani cement industry and analysed a series of financial ratios alongside estimation of productivity growth for the industry. To get a better sense of the results and sensitivity analysis, we also collected data on other similar firms from four industries. Financial analysis results revealed that except for significant capital investment in technology upgrading and capacity additions, privatized firms' performance over the longer-run postreforms/privatization period has been rather less than satisfactory. Peer firms from the private sector, in particular, have done much better in terms of long-term profitability and output (sale) trend. Interestingly, the weaker profitability performance of privatized firms has not been limited just to cement manufacturers but has been very widespread across four other manufacturing industries. This could have been for a variety of reasons, including an increase in financial expenses to meet technology upgrade demands and the resultant bank borrowing to finance the investment alongside government taxation policy etc.

The story for long-run post-reform/privatization productive performance is not that disappointing compared to financial performance. We conclude that the industry recorded a decent productivity growth during the sample period. Overall, productivity growth in the industry has been around 2.8 per cent per annum, coming mainly from technological progress. In the post-privatization period, firms focused on technological development more than the efficient use of resources (catching up). Most of the progress was achieved during the post-reform/privatization period compared to the decline before the reform period. Interestingly, the initial impact of the privatization was 
negligible; however, the industry witnessed a significant productivity growth in the long run. This highlights the fact that in some cases, the benefits of privatization in terms of productivity increase could be realized in the long run if the economic conditions became conducive to the industry and the management had the required freedom after reforms to benefit from favourable conditions. The privatized firms did not do well compared to the industry averages, recording only 1 per cent growth p.a. during the whole sample period and 2 per cent during the post-privatization period. The immediate impact of reforms was also minimal. Contrary to the broader consensus that privatization improves efficiency, a relatively lower growth for the group of privatized firms was achieved as a result of the decrease in efficiency.

The group of private firms, however, outperformed the other two ownership firms, recording a growth of more than 4 per cent p.a. during the sample period and roughly 5 per cent p.a. post reform due to the technological progress. Thus, a relatively favourable macroeconomic environment, further deep regulatory and financial reforms introduced later alongside better quality of management rather than ownership per se were the main drivers of growth. Our multivariate regression results confirm this. Although privatized firms did not outperform privately owned firms, this relatively modest growth has to be taken into account in the context of nonexistent pre-privatization productivity growth and is definitely better than those firms who remained under public ownership after the mass privatization event of 1922. This relatively better performance of privatized firms could also send a positive signal to potential new entrants without the fear of renationalization of the industry. All this could lead to higher competition levels and vertical integration in the industry. 
The rising cement export levels since 2002 could also be an indicator of having reached a stage where, due to improvement in the use of technology, firms are able to compete internationally. Interestingly, South African cement manufacturers recently alleged that the Pakistani cement producers have initiated a dumping policy to capture more of the market share and probably that has only been possible due to modernization of technology, significant capacity additions and more importantly a better use of technology in the post-privatization period. At home, there is a wider consensus that competition levels have been deteriorating since 1992 generally and from 1999 onwards in particular. The benefits of falling marginal and average costs have not been passed on to the consumers. There is a belief that government has been the ultimate beneficiary by collecting more taxes due to an increase in the volume of sales. This issue will be investigated more assiduously in our future research.

\section{References}

Adam, C., Mistry, P. S. 1992. Adjusting privatization: Case studies from developing countries. James Currey.

Aftab, S., Khan, S.R., 1995. Comparative Privatisation Experience in Pakistan: employee vs private ownership. Research report. Pakistan: Sustainable Development Policy Institute (SDPI). Aghion, P., Carlin, W., Schaffer, M., 2002. Competition, innovation and growth in transition: exploring the interactions between policies. Working paper no. 501. USA: The William Davison Institute, University of Michigan Business School.

Amess, K., Roberts, B.M., 2007. The productivity effects of privatization, International Review of Financial Analysis 16(4), 354-366. 
Arocena, P., Oliveros, D., 2012. The efficiency of state-owned and privatized firms: does ownership make a difference? International Journal of Production Economics 140(1), 457-465. Asaftei, G., Kumbhakar, S.C., Mantescu, D., 2008. Ownership, business environment and productivity change. Journal of Comparative Economics 36(3), 498-509.

Atkinson, S.E., Halvorsen, R., 1986. The relative efficiency of public and private firms in a regulated environment: the case of U.S. electric utilities. Journal of Public Economics 29(3), 281294.

Bandyopadhyay, S., 2011. In search of contextual variables in a stochastic DEA framework: effect of regulation on efficiency of Indian cement industry. Journal of the Operational Research Society 62(9), 1621-1637.

Bansak, C., Morin, N., Starr, M., 2007. Technology, capital spending, and capacity utilization. Economic Inquiry, 45(3), 631-645.

Barberis, N., Boycko, M., Shleifer, A., Tsukanova, N., 1996. How does privatization work? Evidence from the Russian shops. Journal of Political Economy 104(4), 764-790.

Bartel, A.P., Harrison, A.E., 2005. Ownership versus environment: disentangling the sources of public-sector inefficiency. Review of Economics and Statistics 87(1), 135-147.

Bejger, S. 2011. Polish cement industry cartel-preliminary examination of collusion existence. Business and Economic Horizons, 4(1), 88-107.

Bejger, S. 2012. Cartel in the Indian cement industry: An attempt to identify it. Economics Discussion Paper, (2012-18).

Bishop, M. R., Kay, J. A. 1989. Privatization in the United Kingdom: lessons from experience. World Development, 17(5), 643-657. 
Boardman, A.E., Vining, A.R., 1989. Ownership and performance in competitive environment: a comparison of the performance of private, mixed and public enterprises. Journal of Law and Economics 32(1), 1-33.

Boubakri, N., Cosset, J. C. 2002. Does privatisation meet the expectations in developing countries? A survey and some evidence from Africa. Journal of African Economies, 11(suppl 1), 111-140.

Boubakri, N., Cosset, J. C., Guedhami, O. 2004. Privatization, corporate governance and economic environment: Firm-level evidence from Asia. Pacific-Basin Finance Journal, 12(1), 65-90.

Boubakri, N., Cosset, J. C., Guedhami, O. 2005. Liberalization, corporate governance and the performance of privatized firms in developing countries. Journal of Corporate Finance, 11(5), 767-790.

Boubakri, N., Cosset, J. C., Guedhami, O., 2008. Privatization in developing countries: performance and ownership effect. Development Policy Review, 26(3), 275-308.

Boubakri, N., Cosset, J.C., 1998. The financial and operating performance of newly privatized firms: evidence from developing countries. Journal of Finance 53(3), 1081- 1110.

Boubakri, N., Cosset, J.C., Guedhami, O., 2005. Liberalization, corporate governance and the performance of newly privatised firms. Journal of Corporate Finance 11(5), 767-90.

Boussofiane, A., Martin, S., Parker, D., 1997. The impact on technical efficiency of the UK privatization programme. Applied Economics 29(3), 297-310.

Boycko, M, Shleifer, A., Vishny, R. W., 1993. A Theory of privatisation Working Paper, Harvard University.

Brissimis, S. N., Delis, M. D., Papanikolaou, N. I. 2008. Exploring the nexus between banking sector reform and performance: Evidence from newly acceded EU countries. Journal of Banking and Finance, 32(12), 2674-2683. 
Brown, J.D., Earle, J.S., Telegdy, A., 2006. The productivity effects of privatization: longitudinal estimates from Hungary, Romania, Russia, and Ukraine. Journal of Political Economy 114(1), 6199.

Çelen, A., Gunalp, B. 2010. Do investigations of competition authorities really increase the degree of competition? An answer from Turkish cement market. Prague Economic Papers, 2, 150-168.

Chen, G., Firth, M., Rui, O. 2006. Have China's enterprise reforms led to improved efficiency and profitability?. Emerging Markets Review, 7(1), 82-109.

Chirwa, E.W., 2001. Privatization and technical efficiency: evidence from the manufacturing sector in Malawi. African Development Review 13(2), 276-307.

Chirwa, E.W., 2004. Industry and firm effects of privatization in Malawian oligopolistic manufacturing. The Journal of Industrial Economics 52(2), 277-289.

Claessens, S., Djankov, S., 1999. Ownership concentration and corporate performance in the Czech Republic. Journal of Comparative Economics 27(3), 498- 513.

Cook, P., Uchida, Y. 2008. The performance of privatised enterprises in developing countries. The Journal of Development Studies, 44(9), 1342-1353.

Cullinane, K., Song, D.W., 2003. A stochastic frontier model of the productive efficiency of Korean container terminals. Applied Economics 35(3), 251-267.

D’Souza, J., Megginson, W., Nash, R., 2002. Determinants of performance improvements in privatized firms: the role of restructuring and corporate governance. Working paper. University of Oklahoma.

D’Souza, J., Megginson, W.L., 1999. The financial and operating performance of privatized firms during the 1990s. Journal of Finance 54(4), 1397- 1438. 
Dewenter, K.L., Malatesta, P.H., 2001. State-owned and privately-owned firms: an empirical analysis of profitability, leverage, and labor intensity. American Economic Review 91(1), 320-334. Djankov, S., Murrell, P., 2002. Enterprise restructuring in transition: a quantitative survey. Journal of Economic Literature 40(3), 739-792.

D'Souza, J., Megginson, W., Nash, R. 2005. Effect of institutional and firm-specific characteristics on post-privatization performance: Evidence from developed countries. Journal of Corporate finance, 11(5), 747-766.

Dyson, R.G., Allen, R., Camanho, A.S., Podinovski, V.V., Sarrico, C.S., Shale, E.A., 2001. Pitfalls and protocols in DEA. European Journal of Operational Research, 132(2), 245-259

Estache, A., Marianela, G., Lourdes, T., 2002. What does privatization do for efficiency? Evidence from Argentinas and Brazils railways. World Development 30(11), 1885-1897.

Fare, R., Grosskoopf, S., Lindgren, B., Ross, P., 1992. Productivity changes in Swedish pharmacies 1980-1989: a nonparametric approach. Journal of Productivity Analysis 3(1), 85-101. Fare, R., Grosskoopf, S., Norris, M., Zhang, Z., 1994. Productivity growth, technical progress, and efficiency change in industrialized countries. American Economic Review 84(1), 66-83.

Fare, R., Grosskopf, S., Lindgren, B., Ross, P., 1989. Productivity developments in Swedish hospitals: a Malmquist output index approach. Discussion paper No 89-3. Southern Illinois University.

Fare, R., Grosskopf, S., Lovell, C.A.K., 1985. The Measurement of Efficiency of Production. Boston: Kluwer-Nijhoff Publishing.

Farinos, J. E., Garcia, C. J., Ibanez, A. M. 2007. Operating and stock market performance of stateowned enterprise privatizations: the Spanish experience. International Review of Financial Analysis, 16(4), 367-389. 
Galal, A., Jones, L.P., Tandon, P., Vogalsang, I., 1994. Welfare Consequences of Selling Public Enterprises. The World Bank.

Ghosh, S. 2008. Does divestment matter for firm performance?: Evidence from the Indian experience. Economic systems, 32(4), 372-388.

Ghulam, Y., Jaffry, S. 2015. Efficiency and productivity of the cement industry: Pakistani experience of deregulation and privatisation. Omega, 54, 101-115.

Harper, J. T. 2001. Short-term effects of privatization on operating performance in the Czech Republic. Journal of Financial Research, 24(1), 119-131.

Huang, Z., Wang, K. 2011. Ultimate privatization and change in firm performance: Evidence from China. China Economic Review, 22(1), 121-132.

Hüschelrath, K., Müller, K., Veith, T. 2013. Concrete shoes for competition: the effect of the German cement cartel on market price. Journal of Competition Law and Economics, 9(1), 97-123. Hüschelrath, K., Müller, K., Veith, T. 2013. Concrete shoes for competition: the effect of the German cement cartel on market price. Journal of Competition Law and Economics, 9(1), 97-123. Jones, D.C., Mygind, N., 2002. Ownership and productive efficiency: evidence from Estonia. Review of Development Economics 6(2), 284-301.

Kay, J.A., Thompson, D.J., 1986. Privatization: a policy in search of a rationale. Economic Journal 96(381), 18-38.

Laffont, J. Tirole, J., 1991. Privatization and incentives. Journal of Law, Economics and Organization, 7(0), 84-105.

Li, D., Moshirian, F., Nguyen, P., Tan, L. W. 2007. Managerial ownership and firm performance: Evidence from China's privatizations. Research in International Business and Finance, 21(3), $396-413$. 
Li, W., Xu, LC, 2004. The impact of privatization and competition in the telecommunications sector around the world. Journal of Law and Economics 47(2), 395-430.

Mathur, I., and Banchuenvijit, W. 2007. The effects of privatization on the performance of newly privatized firms in emerging markets. Emerging Markets Review, 8(2), 134-146.

Megginson, W. L. Netter, J. M., 2001. From state to market: a survey of empirical studies on privatisation. Journal of Economic Literature 39(2), 321-89.

Megginson, W.L., Nash, R.C., Van Randenborgh, M., 1994. The Financial and operating performance of newly privatized firms: an international empirical analysis. Journal of Finance 49(2), 403-452.

Naceur, S. B., Ghazouani, S., Omran, M. 2007. The performance of newly privatized firms in selected MENA countries: The role of ownership structure, governance and liberalization policies. International Review of Financial Analysis, 16(4), 332-353.

Naqvi, N.H., Kemal, A.R., 1997. Privatisation, efficiency and employment in Pakistan, in: How Does Privatisation Work? Essays on Privatisation in Honour of Professor V.V. Ramanadham, Routledge, 11 New Fetter Lane London EC4P 4EE.

Newbery, D. Pollitt, M.G., 1997. The restructuring and privatisation of the CEGB -was it worth it? Journal of Industrial Economics 45(3), 269-304.

Okten, C., Arin, K.P., 2006. The effects of privatization on efficiency: how does privatization work? World Development 34(9), 1537-1556.

Parker, D., Kirkpatrick, C., 2005. Privatisation in developing countries: A review of the evidence and the policy lessons. Journal of Development Studies 41(4), 513-541.

Resende, M., Facanha, L., 2002. Privatization and efficiency in Brazilian telecommunications: an empirical study. Applied Economics Letters 9(12), 823-826. 
Rezitis, A.N., Tsiboukas, K., Tsoukalas, S., 2009. Effects of the European Union farm credit programs on efficiency and productivity of the Greek livestock sector: a stochastic DEA application, 8th Annual EEFS Conference, Current Challenges in the Global Economy: Prospects and Policy Reforms, University of Warsaw, Faculty of Economic and Science, June 4-7, 2009, Warsaw.

Riccardi, R., Oggioni, G., Toninelli, R., 2012. Efficiency analysis of world cement industry in presence of undesirable output: application of data envelopment analysis and directional distance function. Energy Policy 44, 140-152.

Rosenbaum, D. I., Sukharomana, S. 2001. Oligopolistic pricing over the deterministic market demand cycle: some evidence from the US Portland cement industry. International Journal of Industrial Organization, 19(6), 863-884.

Rossi, M.A., 2001. Technical change and efficiency measures: the post privatisation in the gas distribution sector in Argentina. Energy Economics 23(3), 295-304.

Saal, D. S., Parker, D. 2000. The impact of privatization and regulation on the water and sewerage industry in England and Wales: a translog cost function model. Managerial and Decision Economics, 21(6), 253-268.

Saal, D.S., Parker, D., 2000. The impact of privatization and regulation on the water and sewerage industry in England and Wales: a translog cost function model. Managerial and Decision Economics 21(6), 253-268.

Saal, D.S., Parker, D., 2001. Productivity and price performance in the privatized water and sewerage companies of England and Wales. Journal of Regulatory Economics 20(1), 61-90. 
Saal, D.S., Parker, D., Weyman-Jones, T., 2007. Determining the contribution of technical change, efficiency change and scale change to productivity growth in the privatized English and Welsh water and sewerage industry: 1985-2000. Journal of Productivity Analysis 28(1), 127-139.

Salvo, A. 2010. Inferring market power under the threat of entry: The case of the Brazilian cement industry. The RAND Journal of Economics, 41(2), 326-350.

Sappington, D.E., Stiglitz, J.E., 1987. Privatization, information and incentives. Journal of Policy Analysis and Management 6(4), 567-82.

Saygili, S., Taymaz, E., 2001. Privatization, ownership and technical efficiency a study of the Turkish cement industry. Annals of Public and Cooperative Economics 72(4), 581-605.

Shephard, R.W., 1970. Theory of Cost and Production Function. USA: Princeton University Press. Shirley, M., Walsh, P. 2000. Public versus private ownership: The current state of debate. Policy research working paper no. 2420. Washington: World Bank.

Simar, L., Wilson, P. W., 1998a. Sensitivity analysis of efficiency scores: how to bootstrap in nonparametric frontier models. Management Science 44(1), 49-61.

Simar, L., Wilson, P. W., 1998b. Productivity growth in industrialized countries. Discussion paper \#9810. Belgium: Institut de Statistique and CORE, Universite Catholique de Louvain, Louvainla-Neuve.

Simar, L., Wilson, P. W., 1999. Estimating the bootstrapping Malmquist indices. European Journal of Operational Research 115(3), 459-471.

Simar, L., Wilson, P.W., 2007. Estimation and inference in two-stage, semiparametric models of production processes. Journal of Econometrics 136, 31-64.

Steen, F., Sørgard, L. 1999. Semicollusion in the Norwegian cement market. European Economic Review, 43(9), 1775-1796. 
Sun, Q., Tong, W., 2003. China share issue privatization: the extent of its success. Journal of Financial Economics 70(2), 183-222.

Tsekouras, K., Skouras, D., 2005. Productive efficiency and exports: an examination of alternative hypotheses for the Greek cement industry. Applied Economics 37(3), 279-291.

Villalonga, B. 2000. Privatization and efficiency: differentiating ownership effects from political, organizational, and dynamic effects. Journal of Economic Behavior and Organization, 42(1), 4374.

Wang, C., 2005. Ownership and operating performance of Chinese IPOs. Journal of Banking and Finance 29(7), 1835-1856.

Wei, Z., Varela, O., Hassan, M. K. 2002. Ownership and performance in Chinese manufacturing industry. Journal of Multinational Financial Management, 12(1), 61-78.

Wei, Z., Varela, O., 2003. State equity ownership and firm market performance: evidence from Chinas newly privatized firms. Global Finance Journal 14(1), 65-82.

Wheelock, D. C., Wilson, P. W., 1999. Technical progress, inefficiency, and productivity change in U.S. banking, 1984-1993. Journal of Money, Credit and Banking, 31(2), 212-234.

Wilson, P.W., 2008. FEAR: a software package for frontier efficiency analysis. Socio-Economic Planning Sciences 42(4), 247-254.

Wortzel, H., Wortzel, L., 1989. Privatization: not the only answer. World Development 17(5), 633641.

Zeidan, R. M., Resende, M. 2009. Measuring market conduct in the Brazilian cement industry: A dynamic econometric investigation. Review of Industrial Organization, 34(3), 231-244.

Zhang, X., Tang, Z., He, J. 2012. Impact of macro and firm-specific characteristics on postprivatization performance. Chinese economy, 455, 50-91. 
Zofio, J.L., Lovell, C.A.K., 1997. Yet another Malmquist Productivity Index decomposition. Paper presented at the sixth European workshop on efficiency and productivity analysis held in Copenhagen, Denmark. 


\section{Appendix A: Derivation of total factor productivity estimates using translog parametric production function estimation method}

The sensitivity of our DEA Malmquist productivity estimates is tested by estimating a parametric production function. The methodology to estimates popular translog production function is simple and is briefly explained here. Let assume $x$ represents a vector of variable inputs $\mathrm{j}(\mathrm{j}=1, \ldots, \mathrm{J}), \mathrm{y}$ is a scalar output and $t$ is the time trend variable representative of the role of technology, the production function is written as:

$$
y=f(x, t)
$$

By $\log (\ln )$ transforming $x$ and $\mathrm{y}$, individual firms represented by subscript $\mathrm{i}$, time represented by $t$ and statistical noise term $v_{i t}$, translog production function is specified as followed:

$$
\ln y_{i t}=\alpha_{0}+\sum_{j} \alpha_{j} \ln x_{j i t}+\alpha_{t} t+\frac{1}{2}\left\{\sum_{j} \sum_{k} \alpha_{j k} \ln x_{j i t} \ln x_{k i t}+\alpha_{t t} t^{2}\right\}+\sum_{j} \alpha_{j t} \ln x_{j i t} t+v_{i t}
$$

After estimating the above model, the technical change index is obtained by taking the derivatives of time trend $t$ and expressed as:

$$
\text { Technical change }(\mathrm{TC})=\alpha_{\mathrm{t}}+\alpha_{\mathrm{tt}}+\sum_{\mathrm{j}} \alpha_{\mathrm{jt}} \ln x_{j}
$$

Change in total factor productivity is calculated from the above (2) as follows:

$$
\text { Total factor productivity }=T C+(R T S-1) \sum_{J} \varepsilon_{j} \ln \hat{x}_{j}
$$

where RTS is returns to scale and $\varepsilon_{j}$ are input elasticities which are substituted for the input shares:

$$
\varepsilon_{j}=\frac{\partial \ln y}{\ln x_{j}}=\alpha_{j}+\sum_{k} \alpha_{j k} \ln x_{k}+\alpha_{j t} t
$$


One of the advantages of using this approach is that it uses all data at the estimation stage and hence addresses the issue of too few observations in estimating productivity estimates under DEA framework. Following estimates of productivity and technical change does confirm that despite differences in the magnitudes, qualitative conclusions remain same as discussed in the section 8.2.

\begin{tabular}{|c|c|c|c|c|c|c|c|c|}
\hline \multirow[b]{2}{*}{ Overall } & \multicolumn{4}{|c|}{ Total productivity change } & \multicolumn{4}{|c|}{ Technical change } \\
\hline & $\begin{array}{c}\text { Industry } \\
1.030\end{array}$ & Privatized & Public & $\begin{array}{c}\text { Private } \\
1.030\end{array}$ & $\begin{array}{c}\text { Industry } \\
1.031\end{array}$ & Privatized & $\begin{array}{l}\text { Public } \\
1.020\end{array}$ & $\begin{array}{c}\text { Private } \\
1.029\end{array}$ \\
\hline 1987-91 & 1.007 & & 1.008 & 1.006 & 1.007 & & 1.008 & 1.005 \\
\hline $1992-11$ & 1.036 & 1.036 & & 1.036 & 1.037 & 1.037 & & 1.035 \\
\hline $1992-11^{a}$ & 1.035 & 1.037 & & 1.035 & 1.036 & 1.037 & & 1.035 \\
\hline
\end{tabular}

Notes: a. Excluding 2007

\section{Appendix B: Determinants of technical and efficiency change}

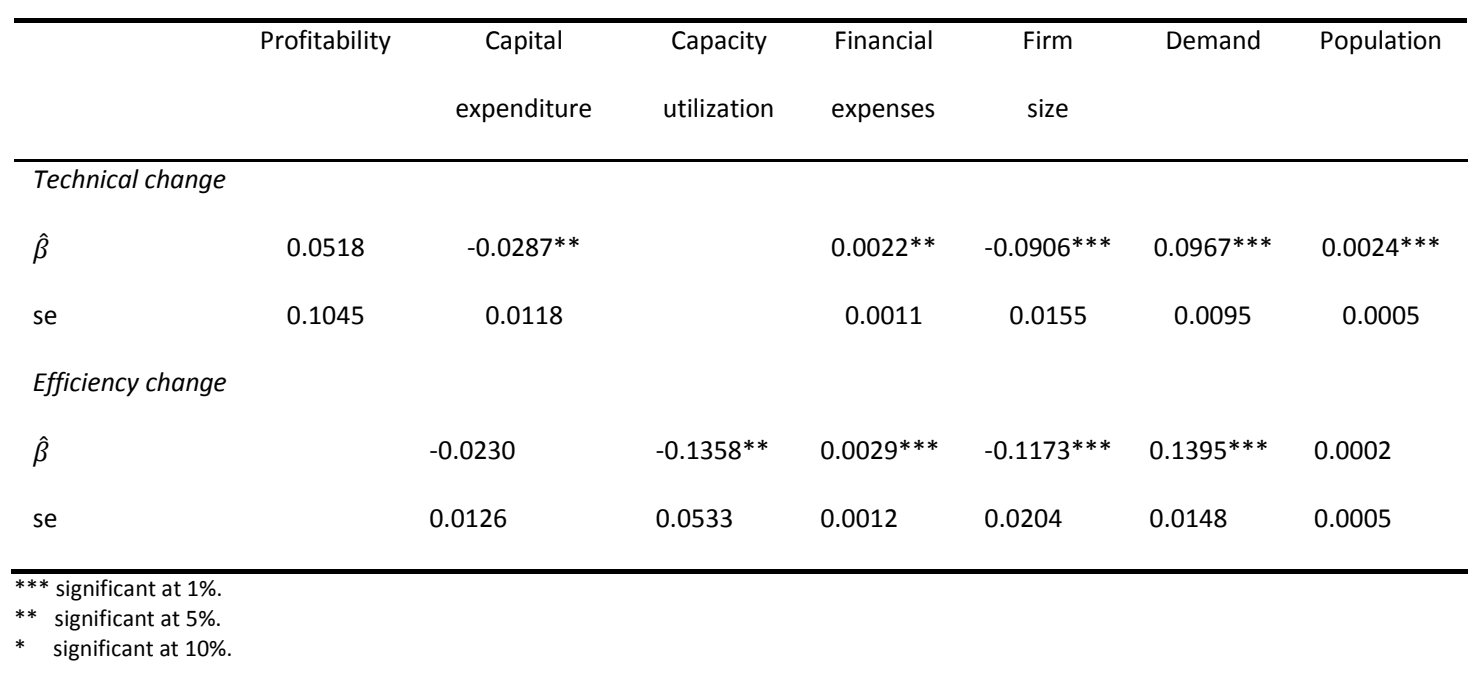

